\title{
MAGNETIC CHITOSAN NANOCOMPOSITES AS ADSORBENTS IN INDUSTRIAL WASTEWATER TREATMENT: A BRIEF REVIEW
}

\author{
MOHAMMAD JAVAD SHARIFI, ${ }^{* * *}$ AMIDEDDIN NOURALISHAHI, ${ }^{*}$ AHMAD HALLAJISANI \\ and MAHDI ASKARI ${ }^{* *}$ \\ "Energy, Environment, and Nanostructure Materials Laboratory, Caspian Faculty of Engineering, \\ University of Tehran, P.O. Box 43841-119, Rezvanshahr, Iran \\ *** Department of Chemical Engineering, Faculty of Engineering, Arak University, \\ P.O. Box 38156-8-8349, Arak, Iran \\ $\bowtie$ Corresponding author: A. Nouralishahi, Nouralishahi@ut.ac.ir
}

Received June 21, 2020

In recent decades, the increasing demand for chemicals has led to producing large volumes of wastewater streams, which should be treated before their release into the environment. Chitosan, a marine polysaccharide derived from chitin, has recently attracted great attention as a promising adsorbent to eliminate ionic dyes and metals from industrial waste streams. Nevertheless, chitosan has its drawbacks, such as its rather weak mechanical properties, low surface area and difficult separation from final streams. The incorporation of magnetic nanoparticles into chitosan may be considered as one of the most effective remedies for the mentioned challenges. This paper addresses the efforts that have been recently made for the application of magnetic nanoparticles/chitosan nanocomposites (MCNCs) as adsorbents in wastewater treatment. In this regard, the synthesis methods, physicochemical properties, and the effects of operational conditions on the performance of MCNCs have been reviewed. The adsorption kinetics, isotherms, and mechanisms are also highlighted.

Keywords: adsorption, chitosan, heavy metals, magnetic nanoparticles, nanocomposite

\section{INTRODUCTION}

There is no doubt that water plays a significant role in different aspects of human life all over the world. ${ }^{1}$ However, this vital resource is being contaminated by various types of pollutants, such as metals, dyes, phosphates and nitrates, sediments, fluoride, toxic and dangerous chemicals, radioactive materials, pharmaceuticals, and personal care products. ${ }^{2-7}$ In addition to their toxicity and adverse effects on the organisms, heavy metals accumulate through the food chain and harm humans as well, and remain sustained for a long period of time. ${ }^{8}$

Conventional separation techniques for the removal of heavy metals from water resources include biological treatment, membrane processes, and electrochemical adsorption methods. ${ }^{9-11}$ These methods usually suffer from shortcomings, such as unpredicted elimination of metal ions, producing toxic sludge, high need for reactants, the large area of liquid surfaces and long period of disposal. ${ }^{12,13}$ Among these techniques, adsorption has been recognized as one of the most popular methods due to its simplicity of operation, cost effectiveness, high efficiency, easy recovery and sludge-free process. ${ }^{14}$ Several research efforts have been made to find appropriate adsorbents for efficient removal of heavy metals, such as activated carbon, zeolite, polymers, functionalized silica and clay. ${ }^{15-17}$

Recently, the application of biopolymers has attracted much attention in water and wastewater treatment. Natural polymers, specifically polysaccharides, have the advantage of wide availability, thus being less expensive, biodegradability and containing different types of functional groups that make them able to adsorb heavy metal ions. ${ }^{18}$ Chitosan is regarded as one of the most significant candidates for adsorption of heavy metals due to its non-toxic, biodegradable hydrophilic nature and environmental friendliness. ${ }^{19,20}$ This natural polymer is a byproduct of the alkaline deacetylation process of chitin, ${ }^{21}$ and it is cheaper and more efficient compared with activated carbon and other 
conventional adsorbents used for water and wastewater treatment. ${ }^{22}$ The advantages of chitosan, including its widespread abundance, bio-degradability, low toxicity, proper chemical resistance, as well as its unique properties, have attracted the researchers' interest in studying its use in widespread applications, from biomedical processes to adsorptive removal of dyes and heavy metals. ${ }^{23}$

Chitosan has a mass of $161 \mathrm{~g}$ per unit monomer and, if it is completely deacetylated, the concentration of amino groups $\left(\mathrm{NH}_{2}\right)$ on its surface is $6.21 \mathrm{mmol} / \mathrm{g}$. The adsorption process of heavy metal ions on the surface of chitosan is mainly affected by the fraction of unprotonated surface amino groups, which are capable of forming coordination with positively charged species. ${ }^{24}$ Moreover, amine groups in the acidic environment lead to adsorption of metal anions through ion exchange, due to their cationic behavior. ${ }^{25}$ Studies by Muzzarelli have shown that chitin and its derivatives can chelate heavy metals, which may be considered as an important property in wastewater treatment industry. ${ }^{26}$ Chelation can be due to the presence of essential functional groups able to form coordination with different metal ions (acetamide, amines, and hydroxyls), being favorable for adsorptive applications. Selectivity is one of the most favorable properties of chitosan. ${ }^{27}$ Nevertheless, some disadvantages related to the weak mechanical and acid-soluble base limit the industrial application of chitosan for large-scale adsorbent reconstruction. ${ }^{28}$ Therefore, the modification of chitosan to achieve the required physical, chemical and mechanical properties is a key issue in order to enhance its potential to be used in contaminant sorption.

In this regard, the preparation of new chitosanbased materials generally includes blending, crosslinking, graft polymerization. ${ }^{8,28-32}$ The chitosan-based functional nanoparticles have the potential to be utilized in environmental, and biomedical applications, such as the adsorption of heavy metal ions or organic pollutants, including hazardous organic chemicals and dyes, drug delivery, targeted magnetic resonance imaging (MRI) ${ }^{33-48}$ Furthermore, the materials can be separated easily from the solution using a bar magnet field and recycled several times, without any reduction of the material. ${ }^{49}$ Simple tuning of the surface properties of magnetic materials can potentially be carried out for desirable applications. The combination of magnetic properties with the functional chitosan can also reveal excellent adsorption and recycling behavior of various pollutants. ${ }^{28,30,32,49-53}$ Varma et al. investigated different classes of chitosan, the properties of its derivatives and ionic capabilities in different situations, explained the adsorption process, and performed the structural analysis of metallic complexes through different approaches, using analytical methods. ${ }^{54}$ Muhd Julkapli et al. proposed the examination of preparation, properties and functional applications of chitosanbased hybrid biocomposites. ${ }^{55}$ Cao et al. used a typical reactive azo dye, brilliant red X-3B (X$3 \mathrm{~B})$ as a model dye pollutant to evaluate the adsorption properties of $\mathrm{MFe}_{3} \mathrm{O}_{4} / \mathrm{CS}$ NPs via batch adsorption experiments. ${ }^{56}$

This review paper tries to thoroughly analyze the adsorptive properties of magnetic chitosan nanocomposites (MCNCs) developed for the removal of pollutants from aqueous solutions. The kinetics, isotherms and mechanisms of the adsorption process of heavy metals onto MCNCs, as well as the structure and physicochemical properties of chitosan are studied in this paper. Also, the effects of process parameters, such as $\mathrm{pH}$, contact time, adsorbent dosage, metal initial concentration, and temperature, on the adsorption process have been reviewed.

\section{CHITOSAN PROPERTIES}

\section{Structure and physicochemical properties of chitosan}

Chitosan is a hydrophobic polymer and a cation derived from the elimination of acetyl chitin in alkaline environment (Fig. 1) ${ }^{26}$ Chitin is the second most common biopolymer in nature, after cellulose. ${ }^{57,58}$ This natural polymer is extracted from different sources, such as crab shell, shrimp, insect cuticles, and cellular septum of some mushrooms and algae species. ${ }^{59}$ Three polymeric forms of chitin have been found: a-, band c-chitin, usually found in shrimp and crab shells, squid pen and stomach cuticles of cephalopod, respectively. In chitosan, the $-\mathrm{OH}$ group on the second carbon atom of the cellulose is replaced by the acetyl $-\mathrm{NH}_{2}$ group. ${ }^{60,61}$ Therefore, chitosan is a type of copolymer that consist of two repeating units, i.e. N-acetyl-2amino-2-D-glucopyranose and 2-amino-2-deoxyD-glucopyranose. Chitosan is a semi-crystalline polymer in its solid state. ${ }^{62}$ Despite the low solubility of chitin caused by its crystal structure through hydrogen bonding, chitosan becomes water soluble following the formation of salts 
with organic acids, such as formic acid, acetic acid, acidic amino acids, ascorbic acid or mineral acid, such as hydrochloric acid used for dissolving chitosan. ${ }^{28}$

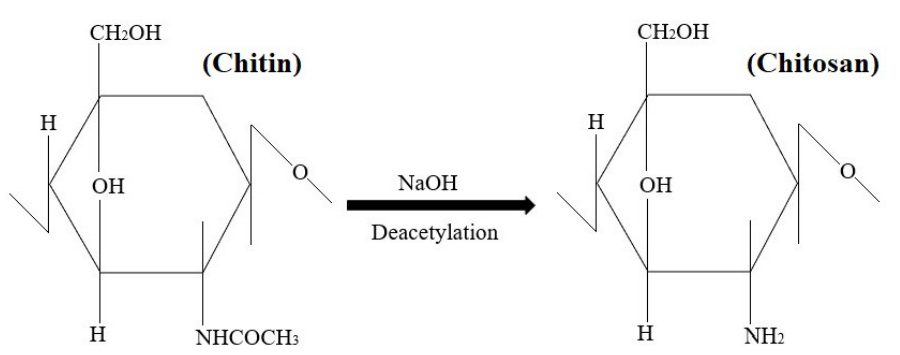

Figure 1: Structures of chitin and chitosan

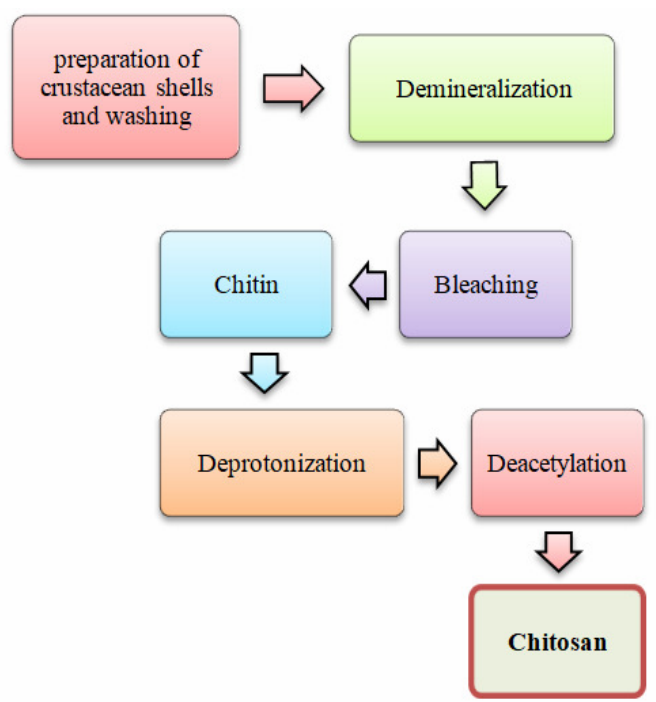

Figure 2: Obtaining chitosan from chitin

Chitosan can be widely used in the removal of heavy metals due to its capability of being combined with metallic ions via adsorption, ion exchange and chelating. ${ }^{63,64}$ Furthermore, the characteristics of chitosan can be improved via chemical and physical processes, in order to prepare chitosan derivatives (achieving new functional groups) or changing the polymer's state (in membrane, nanoparticles, powder and fiber production) ${ }^{20,63,64}$ These processes are used to control the reactivity of polymers (enhancing metal adsorption efficiency, selectivity and $\mathrm{pH}$ change for optimal adsorption), or to increase the kinetics of adsorption. ${ }^{63-65}$ The coordination between chitosan or chitin and metal ions has been examined in several theoretical ${ }^{24,66-71}$ and practical $^{67,72-74}$ studies before, most of which have focused on identification of junctions and more favorable adsorption models. Also, the adsorption of metal ions using chitosan derivatives, such as lateral joint chitosan, porous polyamine chitosan, chitosan composites and new derivatives of chitosan, has been examined. ${ }^{75}$ Chitin is easily obtained from hard shells of shrimp, crab, lobster and also from bacterial cell walls and mushroom mycelia. Processing hard shells often includes protein elimination and solving calcium-based compounds, which are available in crab shells in high concentrations. The obtained chitin is deacetylated using sodium hydroxide (40-45\% $\mathrm{w} / \mathrm{w})$ at $100-120^{\circ} \mathrm{C}$ for a period of $1-3$ hours. The acetylation degree increases by prolonging the treatment time. Deacetylation can eliminate the acetyl groups from the structure and leave the amine groups $\left(\mathrm{NH}_{2}\right){ }^{75}$ Figure 2 shows the general process of chitosan preparation from hard shells.

\section{Methods to improve chitosan properties}

The main goals for modification of chitosan are to increase the stability of the material in 
acidic media, enhance the removal efficiency, better selectivity for heavy metals and to ease its regeneration after the treatment process. ${ }^{76}$ Hence, the modification of chitosan to provide the desired physical, chemical and mechanical properties is a key issue in order to enhance its removal capacity towards dyes, heavy metals and pollutants. ${ }^{28,77}$ Chitosan can chelate toxic pollutants, such as heavy metals and dyes. ${ }^{78}$ Chitosan has been identified as a promising adsorbent for the removal of toxic pollutants from wastewater on the basis of these properties. ${ }^{79}$

\section{Chemical modifications}

Various methods are employed for achieving the chemical modification of chitosan, such as cross-linking with some agents like sodium triphosphate, sodium trimetaphosphate, to enhance its stability in acidic solution, or grafting with different materials, such as hexamethylene, epichlorohydrin, and glutaraldehyde, to increase chelating or complexation properties by introducing functional groups in the structure of chitosan. These methods are illustrated in Figure $3 .^{32,80-86}$

\section{Chitosan-based blends and composites}

The application of polymer/inorganic hybrid nanomaterials has been extensively investigated for the adsorptive removal of various toxic metal ions, dyes, and microorganisms from water and wastewater ${ }^{87}$ These hybrid materials demonstrate high removal capacity and reliable selectivity for the removal of heavy metals from aqueous media. ${ }^{88}$ Nanostructured materials are a new class of materials with high performance with application in a variety of industries, as well as in the environmental sector. $^{30,34,35,41,42,46}$ Several reviews have been published on biosorbents based on chitosan, more or less related to the removal of heavy metals, including on the modification of chitosan and chitosan derivatives for their application as biosorbents for the removal of metals. Magnetic ferrite nanoparticles based nanomaterials include magnetite $\left(\mathrm{Fe}_{3} \mathrm{O}_{4}\right)$ NPs and maghemite $\left(\gamma-\mathrm{Fe}_{2} \mathrm{O}_{3}\right)$ NPs, display finite size and a high surface to volume ratio, resulting in an excellent adsorption capacity for the removal of toxic metal ions. ${ }^{89}$ Interestingly, the chitosan cover not only stabilizes and protects the magnetic particles, but also is used for surface functionalization due to the presence of abundant amine, hydroxyl, and carboxyl groups. ${ }^{90}$ One of the most important advantages of using magnetic composites, along with chitosan, is the easy preparation of the chitosan and nanoparticles intermix by co-precipitation because the functional groups existing on the surface of iron oxide easily react with chitosan and its derivatives. ${ }^{91}$
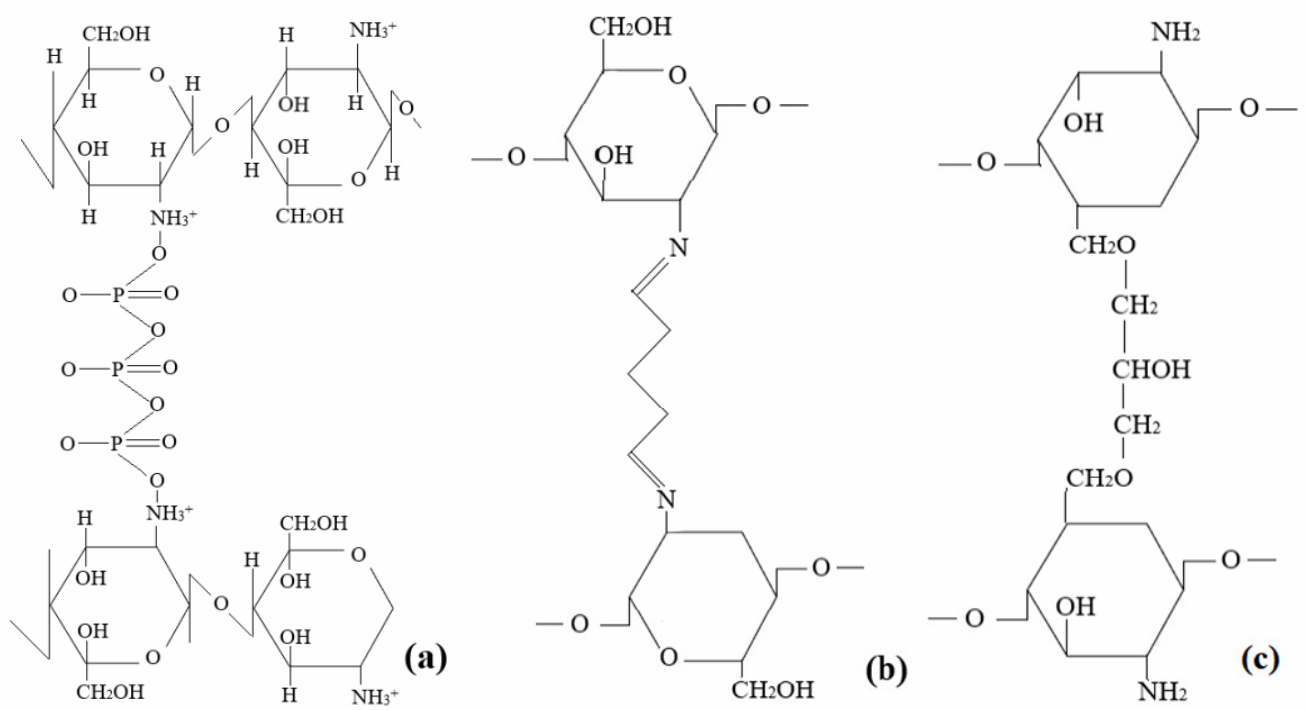

Figure 3: Chitosan crosslinking with a) sodium triphosphate, b) glutaraldehyde, c) epichlorohydrin ${ }^{7}$ 


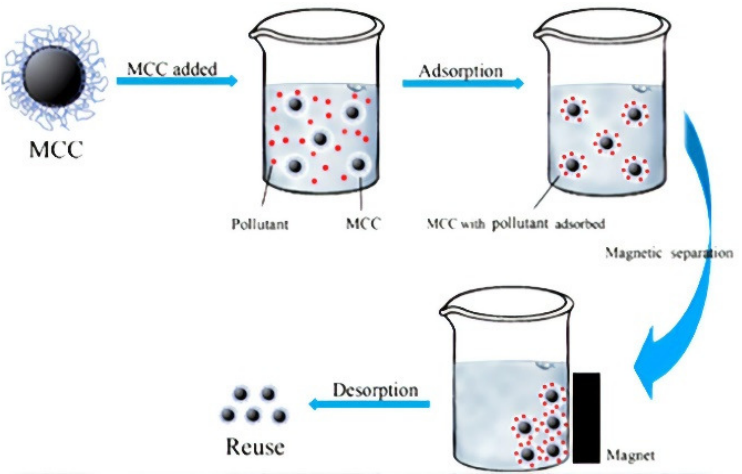

Figure 4: Adsorbent recovery after adsorption process $^{94}$

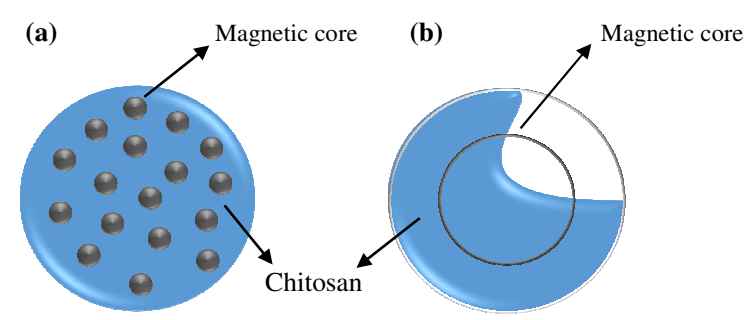

Figure 5: (a) Magnetic multi-cores homogeneously dispersed in chitosan; (b) magnetic core-chitosan shell

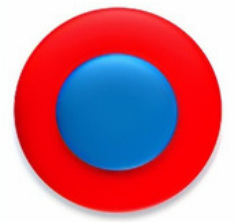

Core-Shell

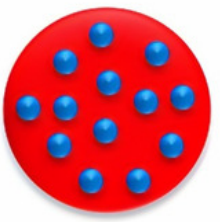

Mosaic

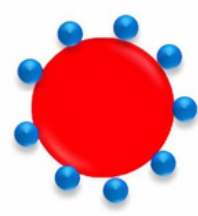

Shell-Core Shell-Core-Shell

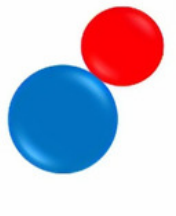

Dumbbell

Figure 6: Fundamental structure of inorganic materials functionalized iron oxide nanoparticles

\section{PHYSICOCHEMICAL PROPERTIES OF CHITOSAN-BASED NANOCOMPOSITES}

Although chitosan possesses a high adsorption capability, its full potential has not been exploited yet because of its low porosity and weak mechanical property. However, physical or chemical modifications can be carried out to overcome these drawbacks. Physical and chemical modifications can prevent dissolution of chitosan in strong acids, improve the mechanical strength and increase the adsorption capacity. ${ }^{92}$ Magnetic adsorbents offer a relatively high surface area, easy separation, and recovery in a magnetic field (Fig. 4). Dispersion of magnetic nanoparticles on the surface of chitosan is a new approach to enhance the performance of chitosan, by increasing the adsorption surface area and/or reducing the required dosage for the adsorption of contaminants. $^{93}$

As illustrated in Figure 5, a magnetic chitosan nanocomposite consists of a chitosan polymer matrix and a dispersed phase of MNPs. Chitosan is studied as a base element for transportation of the magnetic factor, due to its important chemical and biological characteristics. The conspicuous performance of this material has led to a wide range of researches about its synthesis and applications in different scientific fields in recent years, resulting in a significant increase in the number of published papers in scientific journals in this area. ${ }^{95}$

Uncovered iron oxide particles present high chemical activity and easily oxidize if exposed to the air. To avoid this, they are combined or covered with a layer of organic molecules (Fig. 6 ), including small molecules or active surface materials, polymers, biomolecules, or an inorganic layer consisting of, for example, silica, metal or non-metallic elements, metal oxide, metal sulfide, etc. ${ }^{96}$ As illustrated in Figure 6, while iron oxides are normally expected to be the center of such composites, the structure of the inorganic compound functionalized iron oxide can generally be of five types: core-shell, mosaic, shell-core, shell-core-shell, and dumbbell.

As mentioned above, chitosan-based magnetic composites take full advantage of the very easy preparation of chitosan and intermixing particles (chitosan-magnetite), as the existing groups on the iron oxide surface easily react with chitosan and its derivatives. The magnetic particles usually added to chitosan include $\mathrm{Fe}_{3} \mathrm{O}_{4}, \mathrm{Fe}_{2} \mathrm{O}_{3}, \mathrm{NiFe}_{2} \mathrm{O}_{4}$, $\mathrm{CoFe}_{2} \mathrm{O}_{4}, \mathrm{CuFe}_{2} \mathrm{O}_{4}$, and $\mathrm{ZnFe}_{2} \mathrm{O}_{4} . \mathrm{Fe}_{3} \mathrm{O}_{4}$ and $\mathrm{Fe}_{2} \mathrm{O}_{3}$ are used more often than the others, for the following reasons:

1. easy preparation: the sample can be prepared easily and quickly by the coprecipitation method; ${ }^{97-101}$ 
2. easy surface modification: existing hydroxyl groups on the surface can be easily modified by other functional groups ${ }^{63}$

3. easy to use: in light of the paramagnetic properties, the particles are easily separated with an external magnetic field, without any need of centrifuging or filtration; ${ }^{102}$

4. reusability: magnetic particles are usually reusable after appropriate cleaning; ${ }^{103}$

5. excellent extraction equilibrium in aqueous solutions: iron oxide nanoparticles have suitable dispersion and can quickly reach the extraction equilibrium. ${ }^{104}$

\section{Magnetic nanoparticles}

Iron is the fourth most abundant element on the earth, contributing by 5 percent to the earth's cluster, and can be found in most types of clays, granites, and sandstones. ${ }^{38}$ The most usual oxide species of iron are ferrous iron $\left(\mathrm{Fe}^{2+}\right)$, ferric iron $\left(\mathrm{Fe}^{3+}\right)$ and ferryl iron $\left(\mathrm{Fe}^{4+}\right)$.

Figure 7 presents the three most important routes for the synthesis of iron oxide nanoparticles. Chemical synthesis methods, such as bottom-up approaches, allow for the engineering of nanostructures and surface modification. Synthesis procedures like solution- based synthesis methods, similar to physical methods (and unlike many mechanical methods), are capable of producing thin layers, besides nanopowders. ${ }^{46}$ However, chemical methods, such as thermal decomposition, ${ }^{105}$ solvothermal, hydrothermal, ${ }^{35,106}$ microemulsion or reverse micelle, ${ }^{107}$ sol-gel ${ }^{108}$ and chemical precipitation, ${ }^{109}$ need simpler and more affordable facilities compared to physical methods. This is considered as the major advantage both in bench and industrial scales. Chemical precipitation is one of the first and most important chemical approaches for nanoparticle synthesis. This route mainly consists of two different stages: namely, nucleation and growth steps. Controlling the parameters of these two steps enables controlling the final properties of nanoparticles. ${ }^{110}$

\section{Spinel group}

This structure belongs to the compounds with the formula of $\mathrm{AB}_{2} \mathrm{O}_{4}$, where $\mathrm{A}$ is a bivalence cation with atomic radius in the range of $80-110 \mathrm{pm}$, such as $\mathrm{Cu}, \mathrm{Zn}, \mathrm{Fe}, \mathrm{Mg}, \mathrm{B}$ is a trivalent cation with atomic radius in the range of 75-90 pm, such as $\mathrm{Al}, \mathrm{Fe}, \mathrm{Ti}, \mathrm{Co}$, and oxygen ions have an $\mathrm{FCC}$ structure (Fig. 8). In this structure, there are four octagon positions and eight tetrahedron positions.
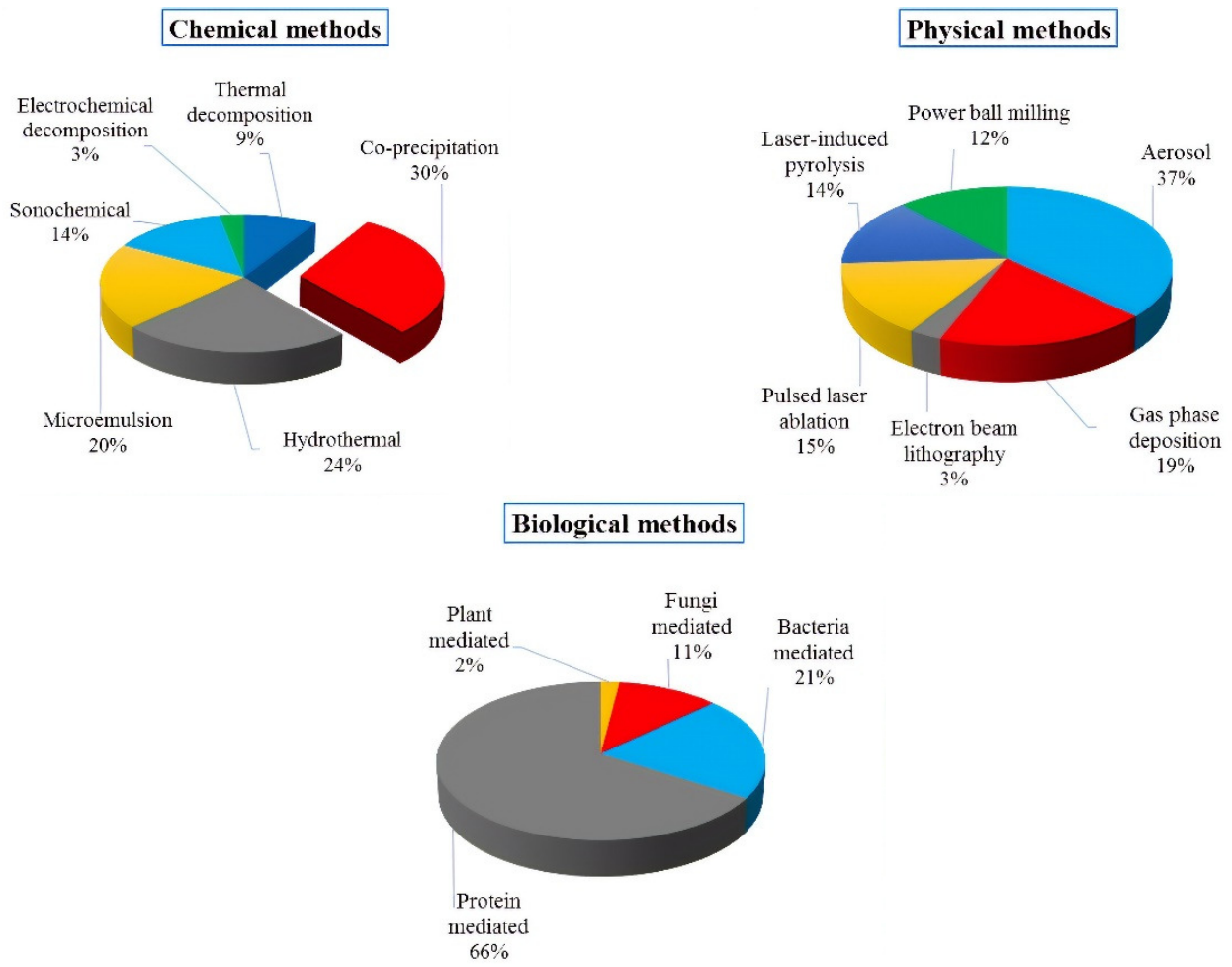

Figure 7: Synthesis methods of iron nanoparticles ${ }^{46}$ 


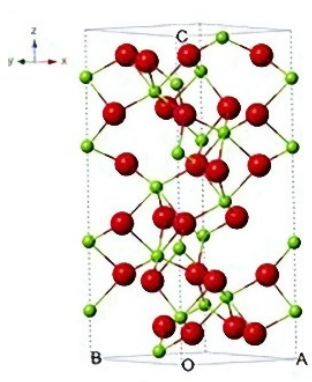

(a) Hematite Rhombohedral, R3c

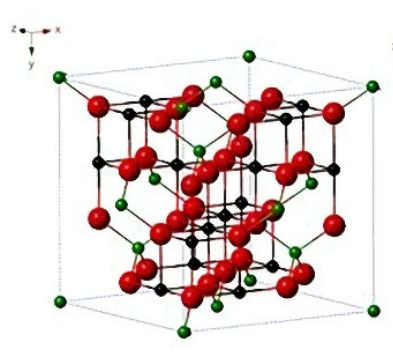

(b) Magnetite Cubic, Fd3m

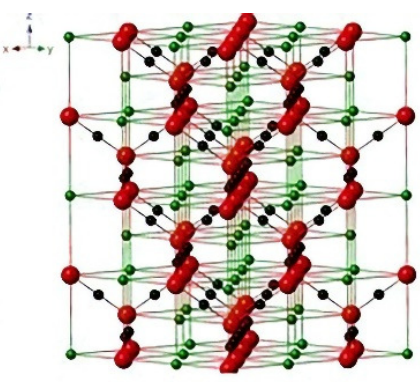

(c) Maghemite Cubic, P4332/Tetragonal, P4,2,2

Figure 8: Structure of a) hematite, b) magnetite, and c) maghemite particles ${ }^{112}$

Eight unique cells of this structure stand in such a manner that a unique cell consisting of 32 oxygen ions, 16 tetrahedron cations and 8 octagon cations results. The spinel structure can be observed in $\mathrm{MgAl}_{2} \mathrm{SO}_{4}, \quad \mathrm{CdFe}_{2} \mathrm{O}_{4}, \mathrm{ZnAl}_{2} \mathrm{O}_{4}$, $\mathrm{FeAl}_{2} \mathrm{O}_{4}, \mathrm{CoAl}_{2} \mathrm{O}_{4}, \mathrm{NiAl}_{2} \mathrm{O}_{4}$ and $\mathrm{MnAl}_{2} \mathrm{O}_{4}$. In reverse spinel, all $\mathrm{A}^{2+}$ ions and half of the $\mathrm{B}^{3+}$ ions are positioned in octagon form, and the other half of the $\mathrm{B}^{3+}$ ions are positioned in tetrahedron form. This structure is more common and it is observed in $\mathrm{FeSO}_{4}$ and several other ferrites, in which magnetic properties are of much importance. ${ }^{111}$

The special surface properties of these types of nanoparticles, their high surface area to volume ratio, outstanding light properties, activation energy, magnetic and electromagnetic properties are the characteristics that distinguish them among nanostructures. ${ }^{113}$ Moreover, these nanoparticles show high efficiency in a vast range of applications, including environmental hygiene. Water hygiene is one of these applications.

In recent years, the research on magnetic nanomaterials has significantly expanded due to their different applications in various areas, such as enzyme stabilization, ${ }^{114}$ wastewater treatment, ${ }^{115}$ targeted drug delivery, DNA separation, ${ }^{116}$ and biosensors. ${ }^{117,118}$

\section{Synthesis of MCNCs}

Several methods have been developed to prepare magnetic chitosan nanocomposites, such as water-in-oil microemulsion, ${ }^{119}$ sol-gel, ${ }^{120}$ coprecipitation methods etc. ${ }^{85,121-123}$

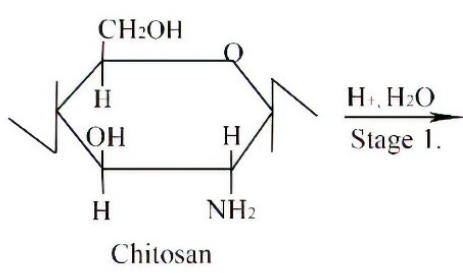

CMNC Synthesis Stage:

1. Dissolution of chitosan

2. Addition of $\mathrm{Fe}(\mathrm{III})$ and $\mathrm{Fe}(\mathrm{II})$ salts to chitosan solution

3. precipitation of chitosan and $\mathrm{Fe}$ salts by $\mathrm{NH}_{4} \mathrm{OH}$ and formation of nanocomposite
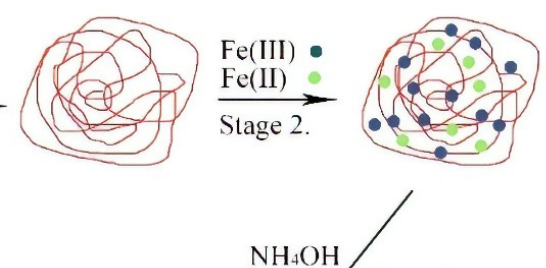

$\mathrm{NH}_{4} \mathrm{OH}$

Stage 3
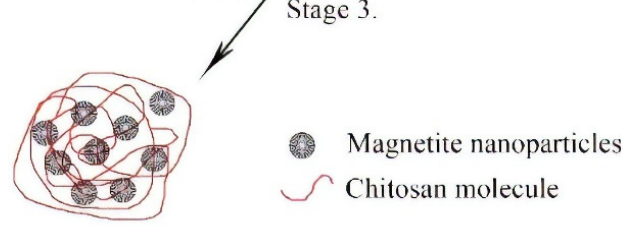

Magnetite nanoparticles
Chitosan molecule

(a)
Co-precipitation is the most conventional method in which ferric and ferrous ions are mixed together. ${ }^{124}$ Chitosan is dissolved in $100 \mathrm{~mL} 2 \%$ $(\mathrm{v} / \mathrm{v})$ of acetic acid aqueous solution for 24 hours. Then, a mixture of iron chloride salts with the $\mathrm{Fe}^{3+} / \mathrm{Fe}^{2+}=2$ ratio is added to the solution at 60
${ }^{\circ} \mathrm{C}$ for 30 minutes (a red-brown mix). In the next step, an ammonium hydroxide or sodium hydroxide solution is added to the chitosan and iron salts. The solution is shaken by hand to avoid sticking of particles together during the addition of the hydroxide salt (Fig. 9). After that, the 
solution is held at ambient temperature for 24 hours and then washed with deionized water several times until it reaches a neutral $\mathrm{pH}$. The particles are finally dried at $70{ }^{\circ} \mathrm{C}$ for 24 hours. To create crosslinking, after the addition of the chitosan and iron salts to the alkaline solution and washing it with deionized water, the produced deposits are soaked in the mentioned crosslinking solution. Then, the particles are washed again and then dried in an oven at $70{ }^{\circ} \mathrm{C} .{ }^{125} \mathrm{An}$ inert gas can be used during the whole experiment to avoid iron oxidization and control the size of nanoparticles. However, the experiments can be also run under atmospheric conditions.

\section{MCNC BIOSORBENTS FOR WASTEWATER TREATMENT}

In light of its ability of chelation with toxic pollutants, such as heavy metals and dyes, both pure and modified chitosan can be regarded as a promising adsorbent for the removal of toxic pollutants from wastewater. ${ }^{28}$ Magnetic chitosan materials represent an important improvement in conventional materials used for the treatment of contaminated water. ${ }^{77}$ The magnetic chitosan basic material is biocompatible and economical. Chitosan can also be modified to selectively and efficiently bind to specific pollutants with different chelating ligands. Although the large surface area-to-volume ratio of nanomaterials contributes to higher reactivity with concomitant improved performance, the occurrence of aggregation, non-specificity, and low stability can limit the use of these nanotechnologies because of lack of functionality. An alternative way to enhance the stability of nanoscale materials might be employing a host material to serve as a matrix or support for the other materials.

The application of natural polymers, such as polysaccharides like chitosan and its derivatives, as adsorbents has attracted considerable attention. ${ }^{59,126,127}$ Several efforts have been made to use chitosan as an adsorbent for different kinds of pollutants, such as metals, dyes, phenol, fluoride, and phthalate, from water and wastewater. ${ }^{128-131}$ The unique structure of chitosan has proved it as a significant adsorbent for the elimination of anionic dyes, such as acid, reactive and direct dyes; while its cationic behavior, due to its protonating amine group, in acidic conditions, leads to adsorption of metal anions through the ionic exchange. ${ }^{23}$ Fang et al. used MNPs of modified magnetite with poly(acrylic acid)- chitosan and carboxymethylated chitosan for the adsorption of alkaline and acidic dyes, respectively. ${ }^{132}$ The color adsorption capacity has increased in both magnetic adsorbents, and this process was linked to the chitosan structure and functional groups of the magnetic adsorbent. ${ }^{92,133}$ Research has shown that modified MNPs with polymers are more efficient and applicable than other magnetic adsorbents. From 1970 to 1980, scientists have recognized the usefulness of materials with magnetic properties for the separation of metallic pollutants, which are sensitive to the magnetic fields from various matrices. ${ }^{134}$ As an example, the reader is referred to the application of MCNC for the elimination of $\mathrm{Cr}(\mathrm{VI}) .{ }^{135}$ The size of the produced particles is in the range of $300 \mathrm{~nm}$. Figure 10 shows the hysteresis loop of magnetic $\left(\mathrm{Fe}_{3} \mathrm{O}_{4}\right)$ nanoparticles (a), $\mathrm{Fe}_{3} \mathrm{O}_{4}$-chitosan nanocomposite (b) at $300 \mathrm{~K}$. The saturation magnetization of the magnetic chitosan nanocomposite was about $20.5 \mathrm{emu} / \mathrm{g}$, which represented a magnetic content of $50 \mathrm{wt} \%$ by comparing with the reference value for the pure magnetite nanoparticles of $40 \mathrm{emu} / \mathrm{g}$.

The chitosan to nanoparticles ratio also affects the adsorption performance. The effect of the chitosan to nanoparticles ratio was measured in a survey aiming to eliminate methyl orange from aqueous solutions. Figure 11 exhibits that increasing this ratio leads to an increase in the adsorption capacity. ${ }^{86}$

FTIR results demonstrated that the precipitation reactions carried out with chitosan led to obtaining composite chitosan-magnetic nanoparticles. ${ }^{136}$ In Figure 12 (a) and (b), the peaks around $3413 \mathrm{~cm}^{-1}$ are related to the hydroxyl $(\mathrm{OH})$ and amine $(\mathrm{NH})$ groups of chitosan. The peak around $1078 \mathrm{~cm}^{-1}$ is related to the carbonyl (CO) groups of chitosan. The peak at $1596 \mathrm{~cm}^{-1}$ is related to the amine group. The 2919 $\mathrm{cm}^{-1}$ and $3041 \mathrm{~cm}^{-1}$ peaks are attributed to the presence of $\mathrm{C}-\mathrm{H}$ groups in chitosan. Also, the peak at $584 \mathrm{~cm}^{-1}$ in Figure 12 (b) is related to the Fe-O link. ${ }^{137}$

Hritcu et al. prepared a chitosan/iron oxide composite for $\mathrm{Cu}(\mathrm{II})$ removal. ${ }^{10} \mathrm{Zhu}$ et al. synthesized novel magnetic chitosan/poly(vinyl alcohol) hydrogel beads for dye removal. ${ }^{138} \mathrm{~A}$ summary of various magnetic chitosan nanocomposites used to treat contaminated water and their adsorption capacity is presented in Table 1 . 


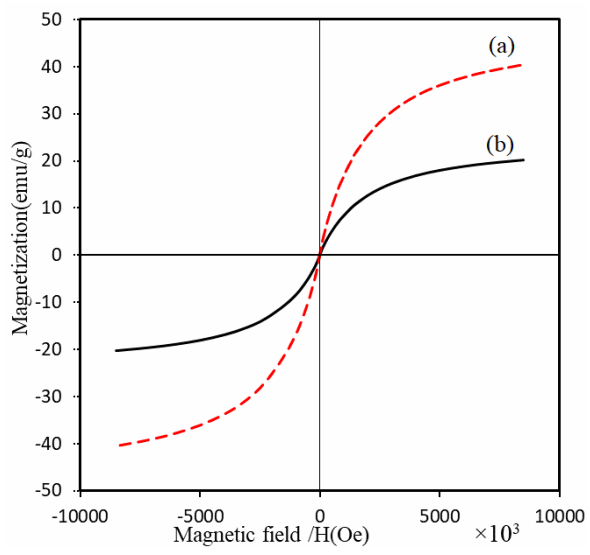

Figure 10: VSM test; a) $\mathrm{Fe}_{3} \mathrm{O}_{4}$ nanoparticles; b) $\mathrm{Fe}_{3} \mathrm{O}_{4}$-chitosan nanocomposite ${ }^{135}$

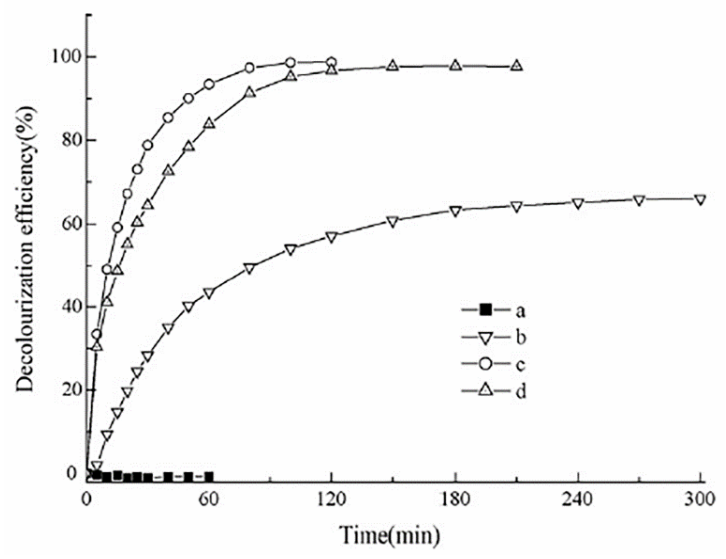

Figure 11: Methyl orange adsorption diagram using a) maghemite nanoparticles, b) crosslinked chitosan, c) maghemite/chitosan (1/10), d) maghemite/chitosan $(2 / 5)^{86}$

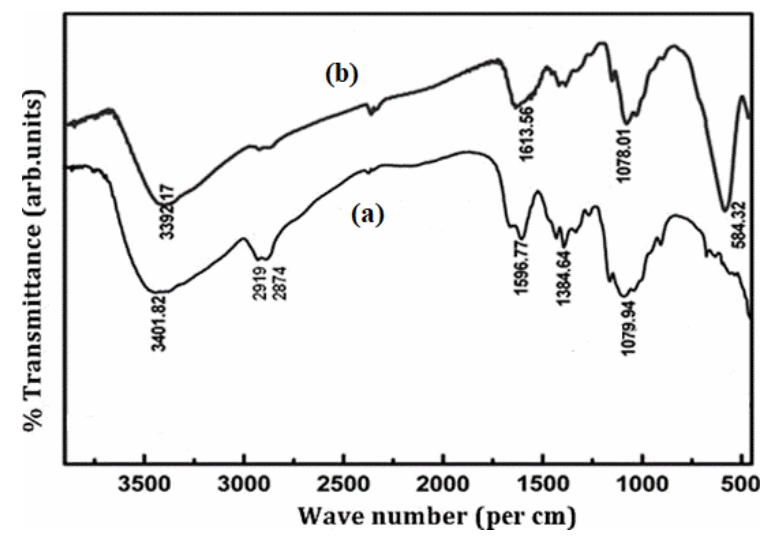

Figure 12: FTIR spectra of (a) chitosan; (b) MCNC measured at room temperature ${ }^{136}$

\section{Parameters affecting MCNC biosorbents performance pH}

The point of zero charge $\left(\mathrm{pH}_{\mathrm{pzc}}\right)$ is an important factor that determines the linear range of $\mathrm{pH}$ sensitivity. It also indicates the type of surface active sites and the adsorption ability of the surface. The adsorption of metals at lower $\mathrm{pH}$ is electrostatic adsorption, while at higher $\mathrm{pH}$ the adsorption is of the ionic type. In addition, at $\mathrm{pH}$ values lower than $\mathrm{pH}_{\mathrm{pzc}}$, the surface charge of the adsorbent is positive, and at $\mathrm{pH}$ values higher than $\mathrm{pH}_{\mathrm{pzc}}$, the surface has a negative electrical charge. ${ }^{152}$ Determining the $\mathrm{pH}_{\mathrm{pzc}}$ aims to find the best $\mathrm{pH}$ range for the adsorption process. Bonding of metal ions to the surface functional groups is highly dependent to the $\mathrm{pH}$ of the solution. In addition, the state of protonation of existing hydroxyl and amine groups on the chitosan surface can highly affect the adsorption of metal ions. ${ }^{153}$ The MCNC also contains different surface functional groups, such as $\mathrm{NH}_{2}, \mathrm{NH}, \mathrm{COOH}, \mathrm{OH}$, and $\mathrm{C}=\mathrm{S} .{ }^{140}$ At higher $\mathrm{H}^{+}$concentration, metal cations have to compete with $\mathrm{H}^{+}$to be adsorbed onto the surface of MCNCs. ${ }^{154,155}$ Therefore, most of the surface functional groups on MCNC are positively charged as a result of the protonation of surface active sites, at acidic $\mathrm{pH}$ values. ${ }^{156}$ This results in electrostatic repulsion between metal ions and the positively charged MCNC surface, which in turn decreases the adsorption capacity of the MCNC. At higher $\mathrm{pH}$ values, due to the presence of more ligands in the adsorbent, like $\mathrm{COO}^{-}$, the density of the negative charge on the surface of the ligand will be increased, so the removal efficiency and the adsorption capacity of cations will be improved. ${ }^{9}$

\section{Contact time}

The contact time between the absorbent and adsorbate will greatly affect the efficiency of the adsorption process. Moreover, in the practical usage of absorbents, the contact time directly reflects the economic efficiency of the process, 
which is dependent on the adsorption kinetics. ${ }^{157}$ Generally, the equilibrium time (the upper limit of contact time) of heavy metal adsorption onto MCNCs is lower than 1 hour, confirming that adsorptive heavy metal removal from water solutions by MCNCs is a quite fast process. Morsi et al. demonstrated that the adsorption of $\mathrm{Hg}$ (II) onto polythiophene modified chitosan/magnetite nanocomposites was initially quite high and then gradually reached equilibrium within $60 \mathrm{~min} .{ }^{158}$

Table 1

Adsorption capacity of magnetic chitosan composites for adsorption of pollutants

\begin{tabular}{|c|c|c|c|c|}
\hline Adsorbent & $\begin{array}{l}\text { Dyes and } \\
\text { metal ions }\end{array}$ & $\mathrm{pH}$ & $\begin{array}{l}\text { Adsorption capacity } \\
(\mathrm{mg} / \mathrm{g})\end{array}$ & Refs. \\
\hline \multirow{2}{*}{ MCC } & $\mathrm{Pb}$ & 6 & 63.33 & \multirow[t]{2}{*}{124} \\
\hline & $\mathrm{Ni}$ & 6 & 52.55 & \\
\hline MCNs & $\mathrm{Co}$ & 5.5 & 27.5 & 139 \\
\hline MCNs & $\mathrm{Cu}$ & 5 & 35.5 & 106 \\
\hline CMMC & $\mathrm{Zn}$ & 5 & 32.16 & 140 \\
\hline MC-Ep & $\mathrm{Cr}$ & 4 & 69.4 & 137 \\
\hline $\mathrm{CMC}$ & $\mathrm{Cu}$ & 6 & 78.13 & 141 \\
\hline \multirow[t]{2}{*}{ MCNs } & $\mathrm{Hg}$ & 6 & 5.62 & \multirow[t]{2}{*}{142} \\
\hline & $\mathrm{Cu}$ & 6 & 103.16 & \\
\hline \multirow[t]{2}{*}{ CSIS } & Co & 6 & 53.51 & \multirow[t]{2}{*}{143} \\
\hline & $\mathrm{Ni}$ & 7 & 40.15 & \\
\hline CMNs & $\mathrm{Fe}$ & 3 & 35.98 & 144 \\
\hline CCMNPs & $\mathrm{Cu}$ & 6 & 96.15 & 16 \\
\hline $\mathrm{M} \gamma-\mathrm{Fe}_{2} \mathrm{O}_{3} / \mathrm{CSCs}$ & MO & 6.6 & 29.46 & 86 \\
\hline \multirow{2}{*}{ CS-MCMs } & MB & 7 & 33.6 & \multirow[t]{2}{*}{145} \\
\hline & $\mathrm{CV}$ & 7 & 86.6 & \\
\hline Chitosan-modified $\mathrm{MnFe}_{2} \mathrm{O}_{4}$ nanoparticles & $\mathrm{Cu}$ & 6.5 & 65.1 & 146 \\
\hline \multirow[t]{2}{*}{ Magnetic chitosan nanoparticles } & $\mathrm{Cr}$ & 3 & 55.8 & 147 \\
\hline & $\mathrm{La}(\mathrm{III})$ & 5 & 17 & \multirow{3}{*}{148} \\
\hline \multirow[t]{2}{*}{ CFCMNBP } & $\mathrm{Nd}(\mathrm{III})$ & 5 & 17.1 & \\
\hline & $\mathrm{Yb}(\mathrm{III})$ & 5 & 18.4 & \\
\hline CG-MCS & $\mathrm{Hg}$ & 7 & 285 & 84 \\
\hline \multirow{2}{*}{ EMCN } & $\operatorname{Pt}(\mathrm{IV})$ & 2 & 171 & \multirow[t]{2}{*}{149} \\
\hline & $\mathrm{Pd}(\mathrm{II})$ & 2 & 138 & \\
\hline $\mathrm{Fe}_{3} \mathrm{O}_{4} / \mathrm{ZrO}_{2} / \mathrm{CS}$ & Tartrazine & 5 & 47.3 & 150 \\
\hline CS-m-GMCNTs & $\mathrm{CR}$ & 4 & 262.9 & 151 \\
\hline
\end{tabular}

Zargoosh et al. used thiosalicylhydrazidemodified magnetic nanoparticles to remove heavy metals ions $\left(\mathrm{Pb}^{2+}, \mathrm{Cd}^{2+}, \mathrm{Cu}^{2+}, \mathrm{Zn}^{2+}\right.$, and $\left.\mathrm{Co}^{2+}\right)$ and showed that the metal ions all rapidly reached equilibrium during $40 \mathrm{~min} .{ }^{159}$ They reported that $95 \%$ of the metal ions were adsorbed at about 25 min. Haldorai et al. investigated the adsorption of $\mathrm{La}$ on a $\mathrm{Fe}_{3} \mathrm{O}_{4} /$ chitosan nanocomposite and achieved $86 \%$ removal after $60 \mathrm{~min}$ of contact time. ${ }^{160}$ Huang et al. showed that the uptake capacity of $\mathrm{Cr}(\mathrm{VI})$ increases with longer contact time and reaches equilibrium at about $60 \mathrm{~min}$ for the three initial $\mathrm{Cr}(\mathrm{VI})$ concentrations investigated, implying that equilibrium has been achieved. ${ }^{137}$ Rahbar et al. indicated the effect of contact time on the removal of $\mathrm{Hg}$ (II) ions from wastewater by MCNs. ${ }^{142}$ They reported that that the adsorption rate was high and equilibrium was reached in 10 minutes with $99.8 \%$ removal percentage of $\mathrm{Hg}(\mathrm{II})$ ions. This rapid adsorption could be evidence for the chemical binding or electrostatic forces between mercury ions and the surface functional groups of MCNs.

\section{Adsorbent dosage}

The amount of the adsorbent used in the process is another significant parameter in the total performance of the system. The amount of the adsorbent should be kept within an optimum range to reach the best removal efficiency. Increasing the adsorbent quantity results in a higher number of active sites available, which leads to enhanced metal removal. ${ }^{161}$ However, a decrease in the adsorption capacity $\left(\mathrm{mg}_{\text {adsorbate }} / \mathrm{mg}_{\text {adsorbent }}\right)$ was observed at an extra amount of adsorbent and was attributed to the 
saturated adsorption active sites as result of the excess. ${ }^{162}$ Aggregation of particles may also have a negative impact on the process because of the decrease in the surface area of the adsorbent. ${ }^{163} \mathrm{In}$ practical applications, a minimum amount of adsorbent that is capable of fulfilling the needs should be employed. Rahbar et al. obtained the optimum values for the independent variables of $\mathrm{pH}$, mercury amount and amount of adsorbent as $5,6.2 \mathrm{mg} / \mathrm{L}$ and $67 \mathrm{mg}$, respectively. ${ }^{164}$ Nguyen et al. studied the effect of adsorbent (CMHNs) dosage on the adsorption capacity and removal efficiency of RB19 dye and $\mathrm{Ni}$ (II) ions, in the range of adsorbent dosage from 0.4 to $2.4 \mathrm{~g} / \mathrm{L} .^{165}$ The effect of adsorbent dosage on arsenite adsorption capacity and removal efficiency was investigated by Lasheen et al., showing that the increase in the amount of nano magnetite chitosan films increases the adsorption of metal ions. The adsorption of metals increased with an increasing amount of the composite up to $2 \mathrm{~g} / \mathrm{L}$. ${ }^{166}$ Yang et al. synthesized and developed MCNPs as an efficient nanoadsorbent for the removal of methyl orange (MO) from industrial wastewater. They selected $5 \mathrm{mg}$ of MCNPs as the optimum amount of adsorbent. ${ }^{167}$

\section{Initial concentration}

In an adsorption process, the initial concentration of the adsorbate plays a key role as the driving force to overcome the mass transfer resistance between liquid and solid phases. ${ }^{156}$ Hence, an improvement in the amount of adsorbed metal ions may be expected by increasing the amount of metal initial concentration. At low concentrations, most of the metal ions adsorb onto the active sites, however, the number of metal ions in the bulk of solution may be insufficient to cover all the active centers on the surface. As a result, the remained free active sites are available to further adsorb metal ions upon increasing initial concentration. At high concentrations, on the other hand, total adsorption capacity stays almost constant due to the fact that the active sites on the surface are already saturated. ${ }^{168}$ Le et al. studied the adsorption of RB19 on magnetic graphene oxide/chitosan nanocomposite beads and observed that when the concentration increased from 20 to $200 \mathrm{mg} / \mathrm{L}$ for RB19 and from 20 to $140 \mathrm{mg} / \mathrm{L}$ for $\mathrm{Ni}(\mathrm{II})$ ions, the removal efficiency decreased from $87.8 \%$ to $42.9 \%$ for RB19 and from $69.1 \%$ to $38.0 \%$ for Ni(II) ions. ${ }^{169}$ They believed that, at higher concentration, the active binding sites on the adsorbent surface were fast saturated by RB19 and $\mathrm{Ni}$ (II) ions, causing the shortage of active sites to bond heavy metal ions and dye. Hritcu et al. synthesized chitosan magnetic micro-spheres by the co-precipitation method to be applied as a novel adsorbent for nickel and cobalt heavy metals in aqueous media. A decrease in the percentage adsorption of both metal ions on the adsorbents with the increase in initial metal ion concentration was observed, while at lower concentrations, more of the metal ions would be removed by the abundant active sites on the adsorbent. ${ }^{10}$ At higher concentrations, more metal ions would be left un-adsorbed because of saturation of the active sites on the adsorbents. ${ }^{170}$ Unlike the decrease observed in percentage adsorption, an increase in adsorption capacity for both metal ions on the adsorbent with the increase in initial metal ion concentration was recorded. ${ }^{171}$ The increase in adsorption capacity with the observed initial concentration of metal ions is attributed to the increasing concentration gradient that acts as a driving force to overcome resistance to the mass transfer of metal ions between the aqueous and solid phase. In fact, higher concentration in solution implies higher amounts of metal ions fixed at the surface of the adsorbent and maximum utilization of the active sites. ${ }^{172}$

\section{Temperature}

Temperature is perceived as an important parameter for the adsorption of metal ions onto adsorbents. ${ }^{173}$ An increase or decrease in temperature during the adsorption process will change the equilibrium capacity of MCNCs. Most metal ion adsorption processes onto MCNCs are exothermic, which means that the adsorption capacity decreases as temperature increases. This is due to the fact that, as temperature rises, the mobility of metal ions enhances, and simultaneously, reduces the adsorption forces between the analyte species and the active sites on the adsorbent surface, which brings on desorption or dechelation from the MCNC. ${ }^{174}$ Monier et al. studied the effect of temperature on $\mathrm{Cu}(\mathrm{II})$, $\mathrm{Co}(\mathrm{II})$, and $\mathrm{Ni}$ (II) ions adsorption by modified magnetic chitosan chelating resin and found that the adsorption process is exothermic. ${ }^{143}$ Jiang et al. investigated the performance of magnetic maghemite/chitosan nanocomposite films and their adsorption characteristics for MO removal from aqueous solution. Thermodynamic studies showed the MO adsorption process was exothermic. ${ }^{119} \mathrm{Cu}(\mathrm{II})$ adsorption onto magnetic 
chitosan nanoparticles was studied in the temperature range from $288.15 \mathrm{~K}$ to $308.15 \mathrm{~K}$. ${ }^{106}$ In this study, the adsorption capacity increased from $29.6 \mathrm{mg} / \mathrm{g}$ to $35.5 \mathrm{mg} / \mathrm{g}$ with the increase in temperature from $288.15 \mathrm{~K}$ to $308.15 \mathrm{~K}$, and the process was denoted as endothermic. Donia et al. ${ }^{175}$ examined the recovery of gold(III) and silver(I) onto a chemically modified magnetic chitosan. Their results indicated that the adsorption process was exothermic, with a spontaneous reaction, which kinetically proceeds according to the pseudo-second-order model. $\mathrm{Hg}$ (II) adsorption onto ethylenediamine-modified magnetic crosslinked chitosan microspheres from aqueous solution was investigated and the analysis demonstrated the adsorption process was exothermic. ${ }^{32}$ Other examples of exothermic processes include adsorption of copper(II) and chromium(III) to magnetic chitosan microcapsules. ${ }^{176}$

\section{Adsorption isotherms}

The adsorption isotherm is one of the most important factors for the adsorption system design. ${ }^{148,166}$ Actually, the adsorption isotherm explains the interaction between the adsorbent and the adsorbed material. ${ }^{121}$ Therefore, it is always considered as an essential factor in determining the capacity of an adsorbent and optimizing its consumption. The isothermic models of Langmuir, Freundlich, DubininRadushkevich (D-R), and Temkin isotherms are widely used to describe isothermic equilibrium sorption. ${ }^{177,178}$ In the Langmuir isotherm, it is assumed that the adsorption occurs homogeneously on the adsorbent, and it actually successfully explains single layer adsorption. On the contrary, the Freundlich isotherm is used to explain heterogeneous systems. ${ }^{143}$ The Langmuir theory is typically applicable with a primitive assumption that the sorption occurs in the adsorbent at specific homogeneous sites. ${ }^{179}$ The adsorption model of Langmuir is expressed as follows:

$$
\frac{C_{e}}{q_{e}}=\frac{C_{e}}{q_{m}}+\frac{1}{q_{m} K_{l}}
$$

where $C_{e}$ is the concentration of metal ion in the solution at equilibrium state in $\mathrm{mg} / \mathrm{L}, q_{e}$ is the metal ion concentration on the adsorbent surface at equilibrium state in $\mathrm{mg} / \mathrm{g}, q_{m}$ is the single layer adsorption capacity in $\mathrm{mg} / \mathrm{g}$, and $K_{l}$ is the Langmuir adsorption constant in $\mathrm{L} / \mathrm{mg}$. Plotting $C_{e} / q_{e}$ against $C_{e}$ gives a straight line with the slope and the intercept equal to $1 / q_{m}$ and $1 /\left(q_{m} K_{l}\right)$, respectively.

In the Langmuir model, a dimensionless coefficient, namely the separation factor $\left(R_{l}\right)$, is used to evaluate the appropriateness of the adsorbent in the adsorption process. This parameter is defined as (Eq. 2):

$R_{l}=\frac{1}{1+C_{\max } K_{l}}$

where $C_{\max }$ is the initial concentration of metal ion in the solution. The isotherm state is explainable through the $R_{l}$ value. For desirable adsorption: $0<R_{l}<1$, and for undesirable adsorption: $R_{l}>1$. For linear adsorption: $R_{l}=1$ and for one-way (irreversible) adsorption: $R_{l}=0 .{ }^{103}$

Besides the single-layer Langmuir adsorption model, other models can be used to explain the adsorption process. As an example, the multilayer Freundlich adsorption model is expressed as (Eq. 3):

$\ln q_{e}=b_{f} \ln C_{e}+\ln K_{f}, b_{f}=\frac{1}{n}$

where $K_{f}$ is the Freundlich constant, explaining the adsorption capacity in $\mathrm{mg} / \mathrm{g}$, and $b_{f}$ is the intensity of adsorption ( $\mathrm{L} / \mathrm{g})$. In this model, for the values of $b_{f}$ lower than 1 , adsorption occurs in low concentrations and the rate of adsorption will be decreased in higher concentrations. ${ }^{103}$ The values of $K_{f}$ and $b_{f}$ are determined from the slope and the intercept of the linear plot of $\ln \left(q_{e}\right)$ vs. $\ln$ $\left(C_{e}\right)$.

The Temkin isotherm model assumes that the adsorption heat of all molecules decreases linearly with the increase in coverage of the adsorbent surface, and that adsorption is characterized by a uniform distribution of binding energies, up to a maximum binding energy. ${ }^{180}$ The linear form of the Temkin isotherm is expressed as (Eq. 4):

$q_{e}=B \ln A+B \ln C_{e}, B=\frac{R T}{b}$

where $A(\mathrm{~L} / \mathrm{g})$ is the equilibrium binding constant and $B=R T / b$ is related to the heat of adsorption, $b$ is the Temkin constant related to the heat of sorption $(\mathrm{J} / \mathrm{mol}), R$ is the ideal gas constant $(8.314$ $\mathrm{J} / \mathrm{Kmol}$ ) and $T$ is the temperature (K).

The Dubinin-Radushkevich isotherm model was used by calculating sorption energy to predict the nature of adsorption processes as physical or chemical (Eq. 5): ${ }^{181}$

$\ln q_{e}=\ln q_{0}-K_{D R} \varepsilon^{2}$

where $q_{e}$ is the amount of adsorbate in the adsorbent at equilibrium $(\mathrm{mg} / \mathrm{g}), \quad q_{0}$ is the 
theoretical isotherm saturation capacity $(\mathrm{mg} / \mathrm{g})$, $K_{D R}$ is the activity coefficient $\left(\mathrm{mol}^{2} / \mathrm{kJ}^{2}\right)$ useful in obtaining the mean sorption energy $E(\mathrm{~kJ} / \mathrm{mol})$ and $\mathcal{E}$ is the Polanyi potential. $\mathcal{E}$ and $E$ are expressed by Equations (6) and (7), respectively:

$\varepsilon=R T \ln \left[1+\frac{1}{C_{e}}\right]$

$E=\left[\frac{1}{\sqrt{2 K_{D R}}}\right]$

In the case of $E$ smaller than $8 \mathrm{~kJ} / \mathrm{mol}$, physical forces prevail, where $E$ is within the range of $8-16 \mathrm{~kJ} / \mathrm{mol}$, the chemical ion exchange mechanism governs adsorption. ${ }^{156}$

\section{Adsorption kinetics}

Studying the process kinetics is essential for the investigation of the factors affecting the reaction rate. The most commonly used models to explain the adsorption process kinetics are the pseudo-first-order, pseudo-second-order and intraparticle diffusion equations. The pseudo-firstorder kinetic equation is based on the adsorbent capacity and it is applicable when adsorption occurs by diffusion in one boundary layer. The pseudo-second-order kinetic equation suggests that the governing mechanism in the adsorption process is chemical adsorption. It also expresses that the chemical adsorption stage is the controlling mechanism of the adsorption process. ${ }^{182,183}$

The linear form of the pseudo-first-order kinetic model is expressed by the following equation: ${ }^{184}$

$\ln \left(q_{e}-q_{t}\right)=\ln q_{e}-K_{1} t$

where $q_{e}$ and $q_{t}$ are the adsorption capacity in equilibrium condition and at time $t$, respectively, $(\mathrm{mg} / \mathrm{g}), K_{1}$ is the rate coefficient $\left(\mathrm{h}^{-1}\right) ; q_{e}$ and $K_{1}$ being the intercept and the slope of the linear diagram of $\ln \left(q_{e}-q_{t}\right)$ vs. $t$.

The pseudo-second-order kinetic model is expressed as follows (Eq. 9): ${ }^{185}$

$\frac{t}{q_{t}}=\frac{1}{K_{2} q_{e}^{2}}+\frac{t}{q_{e}}$

In the pseudo-second-order equation, $K_{2}$ is the pseudo-second-order reaction rate constant (mg/g.h); $q_{e}$ and $K_{2}$ can be obtained from the slope and the intercept of $t / q_{t}$ linear diagram vs. $t$, respectively.

The intraparticle diffusion model is expressed as:

$\mathrm{q}_{\mathrm{r}}=\mathrm{K}_{\mathrm{d}} \mathrm{t}^{1 / 2}$ where $K_{d}$ is the rate constant for intraparticle diffusion (in $\mathrm{mg} / \mathrm{g} \cdot \mathrm{h}^{1 / 2}$ ), and $C$ is the intraparticle diffusion constant (in $\mathrm{mg} / \mathrm{g}$ ). If the intraparticle diffusion is the rate-limiting step, a plot of the solute adsorbed against the square root of the contact time should result in a straight line passing through the origin. In addition, the intraparticle diffusion rate constant is obtained from the curve incline. ${ }^{171}$

Adsorption equilibrium is one of the vital information pieces required for proper adsorption system analysis and design. In most cases, the Langmuir model fits the adsorption data of metal ions and dyes on MCNCs, as evidenced by the data shown in Table 2. This suggests that the adsorbed material forms a monolayer on a surface with a finite number of identical sites that are homogeneously distributed across the adsorbent surface. For a practical application of MCNCs in pollutant removal, knowledge of the kinetics of this process is required. Kinetic models have been developed to analyze experimental data to determine the adsorption mechanism and the potential rate-limiting steps, which may include mass transport and chemical reaction processes. These kinetic models provide valuable information about the adsorbent surface, chemical reaction, and/or diffusion mechanisms, which control the adsorption process. A summary of the best fit of a kinetic model for the removal of metal and dyes using various MCNCs is shown in Table 2. Further, most studies related to the adsorption of metal ions and dyes onto MCNCs also followed the pseudo-second-order model, indicating the chemisorption process (Table 2). A possible explanation for the chemisorption is that most of the MCNCs contain chelating functional groups, including hydroxyl, amine, amino, carboxyl, etc.

\section{Mechanism of the adsorption process}

A major challenge in the adsorption field is to identify the mechanism by which the adsorbent absorbs target pollutants and then evaluate the efficiency of the adsorbent material. Although many papers describe the performance of MCNCs, few determine the mechanism by which the adsorption process takes place. The adsorption mechanism for MCNCs could be more complex than for other materials. Generally speaking, most inorganic and organic pollutants are adsorbed onto the surface of MCNCs through various types of interactions, including ion exchange, physical adsorption, chemical bonding (complexation 
and/or chelation), van der Waals forces etc. ${ }^{204}$ The adsorption mechanisms are significantly influenced by a wide range of factors, such as composite structure, $\mathrm{pH}$ of the solution and the functional groups on the composite. Metal ions generally bind to the MCNC via the available functional groups (hydroxyl, carboxyl, thiol and amine groups) on the composite (Fig. 13).

Table 2

Adsorption of various contaminants by magnetic chitosan based adsorbents

\begin{tabular}{|c|c|c|c|c|c|}
\hline Adsorbent & Contaminants & Isotherm & $\begin{array}{l}\text { Kinetic } \\
\text { model }\end{array}$ & $\begin{array}{c}\text { Adsorption } \\
\text { capacity (mg/g) }\end{array}$ & Refs. \\
\hline \multirow{5}{*}{ NMag-CS } & $\mathrm{Cu}^{2+}$ & & & 123.4 & \multirow{5}{*}{166} \\
\hline & $\mathrm{Pb}^{2+}$ & & & 114.9 & \\
\hline & $\mathrm{Cr}(\mathrm{VI})$ & $\mathrm{L}$ and $\mathrm{F}$ & PSO & 116.2 & \\
\hline & $\mathrm{Cd}^{2+}$ & & & 112.3 & \\
\hline & $\mathrm{Ni}^{2+}$ & & & 109.8 & \\
\hline $\mathrm{Fe}_{3} \mathrm{O}_{4}$-chitosan@bentonite & $\mathrm{Cr}(\mathrm{VI})$ & $\mathrm{L}$ & PSO & 62.1 & 186 \\
\hline Chitosan/magnetite & $\mathrm{Pb}^{2+}$ & $\mathrm{L}$ & - & 63.33 & 124 \\
\hline MACCS & $\mathrm{Ni}(\mathrm{II})$ & $\mathrm{L}$ & PSO & 108.70 & 187 \\
\hline \multirow{2}{*}{ MCPs } & $\mathrm{Cu}(\mathrm{II})$ & $I$ & PSO & 126.58 & \multirow{2}{*}{188} \\
\hline & $\mathrm{Ni}(\mathrm{II})$ & L & PSU & 66.23 & \\
\hline MC-FeS & $\mathrm{Cr}(\mathrm{VI})$ & $\mathrm{R}-\mathrm{P}$ & PSO & 123.42 & \multirow{3}{*}{150} \\
\hline \multirow{2}{*}{$\mathrm{Fe}_{3} \mathrm{O}_{4} / \mathrm{ZrO}_{2} /$ chitosan } & Amaranth & $\mathrm{F}$ & PSO & 99.60 & \\
\hline & Tartrazine & $\mathrm{F}$ & PSO & 47.30 & \\
\hline \multirow{2}{*}{ CLCh } & $\mathrm{Cr}(\mathrm{III})$ & $\mathrm{L}$ & PFO & 66.25 & \multirow[t]{2}{*}{190} \\
\hline & $\mathrm{Cr}(\mathrm{VI})$ & $\mathrm{L}$ & PSO & 449.30 & \\
\hline $\mathrm{Fe}_{3} \mathrm{O}_{4} @ \mathrm{HCCS}$ & Fluoride & $\mathrm{L}$ & - & 2.4 & 191 \\
\hline MCS-GA & $\mathrm{CV}$ & $\mathrm{L}$ & PSO & 105.46 & 192 \\
\hline MCDs & $\begin{array}{c}\text { Food Yellow } 3 \\
\text { Acid } \\
\text { Yellow } 23\end{array}$ & $\mathrm{~L}$ & PSO & $\begin{array}{l}833.33 \\
666.67\end{array}$ & 193 \\
\hline Magnetic chitosan beads & $\mathrm{Sr}^{2+}$ & $\mathrm{L}$ & $\begin{array}{c}\text { Intraparticle } \\
\text { diffusion }\end{array}$ & 11.58 & 194 \\
\hline MGCh & Acid Orange 7 & $\mathrm{~L}$ & PFO & 42.8 & 195 \\
\hline MC-g-PAM & Humic Acid & $\mathrm{L}$ & PSO & 120.77 & \multirow{2}{*}{197} \\
\hline \multirow{3}{*}{$\begin{array}{l}\mathrm{PA}-\mathrm{Ch}-\mathrm{ZnO} / \mathrm{Fe}_{3} \mathrm{O}_{4} \\
\text { Crosslinked magnetic } \\
\text { chitosan } \\
\text { FPCC }\end{array}$} & $\mathrm{Cu}(\mathrm{II})$ & $\mathrm{L}$ & PSO & 328.40 & \\
\hline & $\mathrm{Cu}(\mathrm{II})$ & $\mathrm{L}$ & PFO & 78.13 & 141 \\
\hline & $\mathrm{Ni}(\mathrm{II})$ & $\mathrm{L}$ & PSO & & 198 \\
\hline $\begin{array}{l}\mathrm{Fe}_{3} \mathrm{O}_{4} @ \text { chitosan@ } \\
\text { graphene oxide }\end{array}$ & $\mathrm{MB}$ & $\mathrm{L}$ & PSO & 262 & 199 \\
\hline GOMCS-ILs & $\mathrm{Pb}(\mathrm{II})$ & $\mathrm{L}$ & PSO & 85 & 200 \\
\hline MCGO & $\mathrm{MB}$ & $\mathrm{L}$ & PSO & 95.31 & 201 \\
\hline R-g-Ch & $\begin{array}{c}\text { Phenol } \\
\text { 4- } \\
\text { Chlorophenol }\end{array}$ & $\mathrm{L}$ & PSO & $\begin{array}{c}188.60 \\
99\end{array}$ & 202 \\
\hline Bn-CTS & $\mathrm{Cs}^{+}$ & $\mathrm{L}$ & PSO & 57.10 & 203 \\
\hline
\end{tabular}

These functional groups can react with the various metal species by chelation and ion exchange. $^{32}$ The overall findings suggest that MCNCs have a complex adsorption mechanism, but it can be concluded that chemisorption via the hydroxyl and/or amine groups of chitosan and additional chemically functional groups (thiol, amino, carboxyl, etc.) is the predominant mechanism. An ion exchange mechanism also plays an important role in the adsorption process. $^{31}$ 


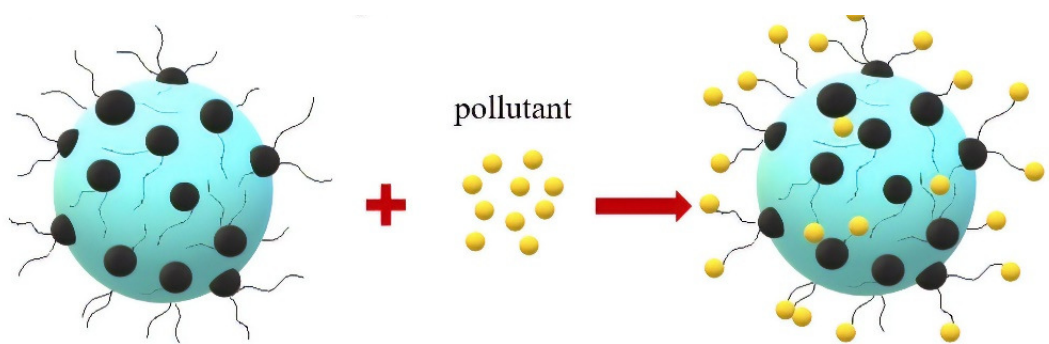

Figure 13: A schematic of MCNCs and their use as pollutant adsorbent

\section{CONCLUSION}

In this review, we have focused on the recent developments in the removal of metal ions and dyes from wastewater using MCNCs. Chitosanbased nanocomposites have higher potential for the adsorption of dyes, metal ions, thus they might be a good alternative to remove pollutants from water and wastewater. MCNCs can also be modified with different chelating ligands for selective and efficient binding to specific pollutants. MCNCs offer a wide range of features, including fast adsorption, easy separation and recovery, environmental friendliness and strong chelating capabilities. Variables influencing the sorption capacity, namely solution $\mathrm{pH}$, metal ion initial concentration, sorbent mass, adsorption time, temperature and adsorption kinetics and isotherms were investigated. Analysis of the adsorption mechanisms reveals that chitosan amine and hydroxyl groups are primarily responsible for binding inorganic and organic pollutants. Nanotechnology can, therefore, be considered as a powerful tool of the $21^{\text {st }}$ century allowing protecting the environment and improving environmental quality.

\section{SYMBOLS USED}

\begin{tabular}{|c|c|c|c|c|c|}
\hline$b_{f}$ & $\mathrm{~L} / \mathrm{g}$ & absorption intensity & $K_{d}$ & $\mathrm{~g} / \min ^{1 / 2}$ & $\begin{array}{l}\text { the rate constant for intraparticle } \\
\text { diffusion }\end{array}$ \\
\hline$C_{a}$ & $\mathrm{mg} / \mathrm{L}$ & $\begin{array}{l}\text { concentration of metal ion } \\
\text { on absorbent }\end{array}$ & $R$ & - & $\begin{array}{l}\text { examine the effects of reactants } \\
\text { concentration }\end{array}$ \\
\hline$C_{e}$ & $\mathrm{mg} / \mathrm{L}$ & equilibrium concentration & $R^{2}$ & - & correlation coefficient \\
\hline$C_{i}$ & $\mathrm{mg} / \mathrm{L}$ & initial concentration & $R_{l}$ & - & separation factor \\
\hline$C_{\max }$ & $\mathrm{mg} / \mathrm{L}$ & maximum concentration & $q_{e}$ & $\mathrm{mg} / \mathrm{g}$ & absorption capacity \\
\hline$K_{l}$ & $\mathrm{~L} / \mathrm{min}$ & $\begin{array}{l}\text { pseudo-first-order rate } \\
\text { coefficient }\end{array}$ & $q_{m}$ & $\mathrm{mg} / \mathrm{g}$ & single layer absorption capacity \\
\hline$K_{2}$ & $\begin{array}{l}\mathrm{mg} / \mathrm{g} \\
\mathrm{min}\end{array}$ & $\begin{array}{l}\text { pseudo-second-order rate } \\
\text { coefficient }\end{array}$ & $q_{t}$ & $\mathrm{mg} / \mathrm{g}$ & absorption capacity at time $\mathrm{t}$ \\
\hline$K_{l}$ & $\mathrm{~L} / \mathrm{mg}$ & $\begin{array}{l}\text { Langmuir absorption } \\
\text { constant }\end{array}$ & $T$ & $\mathrm{~K}$ & temperature \\
\hline$K_{f}$ & $\mathrm{mg} / \mathrm{g}$ & Freundlich constant & $t$ & $\min$ & time \\
\hline
\end{tabular}

\section{ABBREVIATIONS}

$\begin{array}{ll}\text { Bn-CTS } & \begin{array}{l}\text { Magnetic bentonite-chitosan } \\ \text { hybrid beads } \\ \text { Chitosan-coated magnetic } \\ \text { nanoparticles } \\ \text { Magnetic iron oxide and } \\ \text { deposited in crosslinked } \\ \text { chitosan }\end{array} \\ \text { CLCh } & \begin{array}{l}\text { Cross-linked magnetic } \\ \text { chitosan }\end{array} \\ \text { CMC } & \begin{array}{l}\text { Cross-linked magnetic } \\ \text { modified chitosan }\end{array} \\ \text { CMMC } & \end{array}$

MCC Magnetic chitosan composites Modified magnetic chitosan microparticles

MC-Ep Magnetic chitosanepichlorohydrin

MC-FeS

MCGO
Chitosan-stabilized magnetic $\mathrm{FeS}$ Magnetic chitosan and graphene oxide and multiwalled carbon nanotubes 


\begin{tabular}{|c|c|c|c|}
\hline CMNs & $\begin{array}{l}\text { Chitosan-magnetite } \\
\text { nanocomposites }\end{array}$ & MC-g-PAM & $\begin{array}{l}\text { Magnetically modified } \\
\text { chitosan-grafted } \\
\text { polyacrylamide }\end{array}$ \\
\hline CR & Congo Red & MCNC & $\begin{array}{l}\text { Magnetic chitosan } \\
\text { nanocomposites }\end{array}$ \\
\hline CS-MCMs & $\begin{array}{l}\text { Chitosan magnetic composite } \\
\text { microspheres }\end{array}$ & MCNs & $\begin{array}{l}\text { Magnetic chitosan } \\
\text { nanoparticles }\end{array}$ \\
\hline $\begin{array}{l}\text { CS-m- } \\
\text { GMCNTs }\end{array}$ & $\begin{array}{l}\text { Chitosan-modified magnetic } \\
\text { graphitized multi-walled } \\
\text { carbon nanotubes }\end{array}$ & MCS-GA & $\begin{array}{l}\mathrm{Fe}_{3} \mathrm{O}_{4} / \text { Chitosan/glutaraldehyde } \\
\text { nanocomposites }\end{array}$ \\
\hline CSIS & $\begin{array}{l}\text { Cross-linked magnetic } \\
\text { chitosan-isatin Schiff"s base } \\
\text { resin }\end{array}$ & MGCh & $\begin{array}{l}\text { Magnetic graphene/chitosan } \\
\text { nanocomposite }\end{array}$ \\
\hline CS & Chitosan & MNPs & Magnetic nanoparticles \\
\hline $\mathrm{CV}$ & Crystal violet & MNP-NWS & $\begin{array}{l}\text { Magnetic nanoparticles- } \mathrm{NaOH} \\
\text { treated wheat straw }\end{array}$ \\
\hline CFCMNBP & $\begin{array}{l}\text { Cysteine-functionalized } \\
\text { chitosan magnetic nano-based } \\
\text { particles }\end{array}$ & MO & Methyl orange \\
\hline EMCN & $\begin{array}{l}\text { Ethylenediamine-modified } \\
\text { magnetic chitosan } \\
\text { nanoparticles }\end{array}$ & MCPs & Magnetic chitosan particles \\
\hline $\mathrm{Fe}_{3} \mathrm{O}_{4} @ \mathrm{HCCS}$ & $\begin{array}{l}\text { Magnetic iron oxide encrusted } \\
\text { hydrocalumite-chitosan }\end{array}$ & $\begin{array}{l}\mathrm{M} \gamma- \\
\mathrm{Fe}_{2} \mathrm{O}_{3} / \mathrm{CSCs}\end{array}$ & $\begin{array}{l}\text { Magnetic } \gamma-\mathrm{Fe} 2 \mathrm{O} 3 / \text { crosslinked } \\
\text { chitosan composites }\end{array}$ \\
\hline FPCC & $\begin{array}{l}\text { Nanochitin-contained } \\
\text { magnetic chitosan microfibers }\end{array}$ & NMag-CS & $\begin{array}{l}\text { Nanomagnetite chitosan } \\
\text { (NMag-CS) film }\end{array}$ \\
\hline GOMCS-ILs & $\begin{array}{l}\text { Graphene oxide and magnetic } \\
\text { chitosan-ionic liquids }\end{array}$ & $\begin{array}{l}\mathrm{PA}-\mathrm{Ch}- \\
\mathrm{ZnO} / \mathrm{Fe}_{3} \mathrm{O}_{4}\end{array}$ & $\begin{array}{l}\text { Polyaniline modified chitosan } \\
\text { embedded with } \mathrm{ZnO} / \mathrm{Fe}_{3} \mathrm{O}_{4} \\
\text { nanocomposites }\end{array}$ \\
\hline MACCS & $\begin{array}{l}\text { Magnetic activated } \\
\text { carbon/chitosan composite } \\
\text { beads }\end{array}$ & R-g-Ch & $\begin{array}{l}\text { Porous magnetic resin grafted } \\
\text { chitosan }\end{array}$ \\
\hline MB & Methyl blue & R-P & Redlich-Peterson \\
\hline
\end{tabular}

\section{REFERENCES}

1 C. Xiong, Y. Li, G. Wang, L. Fang, S. Zhou et al., Chem. Eng. J., 259, 257 (2015), https://doi.org/10.1016/j.cej.2014.07.114

2 M. F. Hamza, J.-C. Roux and E. Guibal, Chem. Eng. J., 344, $124 \quad$ (2018), https://doi.org/10.1016/j.cej.2018.03.029

3 M. F. Hamza, Y. Wei, H. I. Mira, A. A. H. AbdelRahman and E. Guibal, Chem. Eng. J., 362, 310 (2019), https://doi.org/10.1016/j.cej.2018.11.225

4 J. Li, J. Cai, L. Zhong, H. Cheng, H. Wang et al., Appl. Clay Sci., 167, 9 (2019), https://doi.org/10.1016/j.clay.2018.10.003

5 M. L. Rahman, T. Biswas, M. Sarkar, M. Yusoff, M. Sarjadi et al., J. Mol. Liq., 243, 616 (2017), https://doi.org/10.1016/j.molliq.2017.08.096

6 N. Sahebjamee, M. Soltanieh, S. M. Mousavi and A. Heydarinasab, Carbohyd. Polym., 210, 264 (2019), https://doi.org/10.1016/j.carbpol.2019.01.074

7 W. S. Wan Ngah, C. S. Endud and R. Mayanar, React. Funct. Polym., 50, 181 (2002), https://doi.org/10.1016/S1381-5148(01)00113-4

8 M. Jaishankar, T. Tseten, N. Anbalagan, B. B. Mathew and K. N. Beeregowda, Interdiscip. Toxicol., 7, 60 (2014), https://doi.org/10.2478/intox-2014-0009

9 R. H. Crist, K. Oberholser, N. Shank and N. Ming, Environ. Sci. Technol., 15, 1212 (1981), https://doi.org/10.1021/es00092a010

10 D. Hritcu, G. Dodi and I. M. Popa, Int. J. Chem. Eng., 4, 364 (2012).

11 B. Volesky and Z. R. Holan, Biotechnol. Prog., 11, 235 (1995), https://doi.org/10.1021/bp00033a001

12 R. Kandisa and N. S. Kv, J. Biorem. Biodegrad., 07, 371 (2016), https://doi.org/10.4172/21556199.1000371

13 S. Sivamani and L. G. Beslin, Int. J. Biosci. Tech., 2, 974 (2009), https://doi.org/10.5281/zenodo.1436044 
14 P. Miretzky and A. F. Cirelli, J. Hazard. Mater., 167 10

(2009),

https://doi.org/10.1016/j.jhazmat.2009.01.060

15 J. Song, H. Kong and J. Jang, J. Colloid Interface Sci., 359, $505 \quad$ (2011), https://doi.org/10.1016/j.jcis.2011.04.034

16 Z. Y. Ting, H.-L. Nie, C. Branford-White, Z.-Y. He and L.-M. Zhu, J. Colloid Interface Sci., 330, 29 (2008), https://doi.org/10.1016/j.jcis.2008.10.026

17 M. A. A. Zaini, Y. Amano and M. Machida, J. Hazard. Mater., 180, $552 \quad$ (2010), https://doi.org/10.1016/j.jhazmat.2010.04.069

18 S. Olivera, H. B. Muralidhara, K. Venkatesh, V. K. Guna, K. Gopalakrishna et al., Carbohyd. Polym., 153, 600 (2016),

https://doi.org/10.1016/j.carbpol.2016.08.017

19 N. Li and R. Bai, Ind. Eng. Chem. Res., 45, 7897 (2006), http://dx.doi.org/10.1021/ie060514s

20 M. Rinaudo, Prog. Polym. Sci., 31, 603 (2006), https://doi.org/10.1016/j.progpolymsci.2006.06.001

21 S. K. Yong, M. Shrivastava, P. Srivastava, A. Kunhikrishnan and N. Bolan, Rev. Environ. Contam. Toxicol., 233, 1 (2015), http://dx.doi.org/10.1007/9783-319-10479-9_1

22 A. Bhatnagar and M. Sillanpää, Adv. Colloid Interface Sci., $\quad \mathbf{1 5 2}, \quad 26 \quad$ (2009), https://doi.org/10.1016/j.cis.2009.09.003

${ }_{23}$ G. Crini and P.-M. Badot, Prog. Polym. Sci., 33, 399

(2008),

https://doi.org/10.1016/j.progpolymsci.2007.11.001

24 O. A. C. Monteiro and C. Airoldi, J. Colloid Interface Sci., $\quad \mathbf{2 1 2}, \quad 212 \quad$ (1999), https://doi.org/10.1006/jcis.1998.6063

25 M. Ziegler-Borowska, D. Chełminiak, T. Siódmiak, A. Sikora, M. Piotr Marszałł et al., Mater. Lett., 132, 63 (2014), https://doi.org/10.1016/j.matlet.2014.06.020

26 R. A. A. Muzzarelli, Carbohyd. Polym., 84, 54 (2011), https://doi.org/10.1016/j.carbpol.2010.12.025

27 R. Schmuhl, H. Krieg and K. Keizer, Water S.A., 27, 1 (2001), http://dx.doi.org/10.4314/wsa.v27i1.5002

28 J. Wang and C. Chen, Bioresour. Technol., 160, 129

(2014),

https://doi.org/10.1016/j.biortech.2013.12.110

29 M. Ahmad, K. Manzoor and S. Ikram, Int. J. Biol.

Macromol., $\quad \mathbf{1 0 5}, \quad 190 \quad$ (2017),

https://doi.org/10.1016/j.ijbiomac.2017.07.008

30 A. Galhoum, M. Mafhouz, N. Gomaa, T. Vincent and E. Guibal, Hydrometallurgy, 168, 127 (2017), http://dx.doi.org/10.1016/j.hydromet.2016.08.011

31 M. K. Sureshkumar, D. Das, M. B. Mallia and P. C. Gupta, J. Hazard. Mater., 184, 65 (2010), https://doi.org/10.1016/j.jhazmat.2010.07.119

32 L. Zhou, Z. Liu, J. Liu and Q. Huang, Desalination, 258, 41

(2010), https://doi.org/10.1016/j.desal.2010.03.051

33 S. Das, B. Sen and N. Debnath, Environ. Sci. Pollut. Res., 22, $18333 \quad$ (2015), http://dx.doi.org/10.1007/s11356-015-5491-6
34 F. D. Guerra, M. F. Attia, D. C. Whitehead and F. Alexis, Molecules (Basel), 23, 1760 (2018), http://dx.doi.org/10.3390/molecules23071760

35 E. H. Kim, H. S. Lee, B. K. Kwak and B.-K. Kim, J. Magn. Magn. Mater., 289, 328 (2005), https://doi.org/10.1016/j.jmmm.2004.11.093

36 D. K. Kim, Y. Zhang, W. Voit, K. V. Rao, J. Kehr et al., Scr. Mater., 44, 1713 (2001), http://dx.doi.org/10.1016/S1359-6462(01)00870-3

37 J.-E. Kim, J.-Y. Shin and M.-H. Cho, Arch. Toxicol., $\quad \mathbf{8 6}, \quad 685 \quad$ (2012), http://dx.doi.org/10.1007/s00204-011-0773-3

38 A.-H. Lu, E. L. Salabas and F. Schüth, Angew. Chem. Int. Ed., 46, 1222 (2007), http://dx.doi.org/10.1002/anie.200602866

39 D. Maity and D. Agrawal, J. Magn. Magn. Mater., 308,

46

(2007),

http://dx.doi.org/10.1016/j.jmmm.2006.05.001

40 K. Niemirowicz-Laskowska, K. Markiewicz, A. Wilczewska and H. Car, Adv. Med. Sci., 57, 1 (2012), http://dx.doi.org/10.2478/v10039-012-0031-9

41 F. Patrizia, M. Rita, T. Lorena, F. Giovanni De and N. Fiore Pasquale, Mini-Rev. Med. Chem., 16, 668 (2016),

http://dx.doi.org/10.2174/13895575156661507091051 29

42 J. R. Peralta-Videa, L. Zhao, M. L. Lopez-Moreno, G. de la Rosa, J. Hong et al., J. Hazard. Mater., 186, 1 (2011), https://doi.org/10.1016/j.jhazmat.2010.11.020

43 Y. Serge, L. Tim, E. Perry and G. Frank, Curr. Pharm. Des., 19, 493 (2013) http://dx.doi.org/10.2174/1381612811306030493

${ }^{44}$ Q. Wan, L. Xie, L. Gao, Z. Wang, X. Nan et al., $\begin{array}{llll}\text { Nanoscale, } & 5, & 744 & \text { (2012), }\end{array}$ http://dx.doi.org/10.1039/c2nr32438e

${ }^{45} \mathrm{~S}$. Wu, A. Sun, F. Zhai, J. Wang, W. Xu et al., Mater. $\quad$ Lett., $\quad$ 65, $1882 \quad$ (2011), https://doi.org/10.1016/j.matlet.2011.03.065

46 P. Xu, G. M. Zeng, D. L. Huang, C. L. Feng, S. Hu et al., Sci. Total Environ., 424, 1 (2012), https://doi.org/10.1016/j.scitotenv.2012.02.023

47 Y. Zhai, F. Liu, Q. Zhang and G. Gao, Colloids Surf., $\quad$ A, 332, $98 \quad$ (2009), https://doi.org/10.1016/j.colsurfa.2008.09.001

48 L. Zhang, W.-F. Dong and H.-B. Sun, Nanoscale, 5, $7664 \quad$ (2013), http://dx.doi.org/10.1039/C3NR01616A

49 K. Z. Elwakeel, A. A. Atia and E. Guibal, Bioresour. Technol., 160, 107 (2014), https://doi.org/10.1016/j.biortech.2014.01.037

50 A. Galhoum, M. Mafhouz, A. Atia, S. AbdelRehem, N. Gomaa et al., Ind. Eng. Chem. Res., 54, 12374 (2015), https://doi.org/10.1021/acs.iecr.5b03331 51 T. Li, Q. Chen, L. Zhou, Z. Le, Y. Wang et al., J. Radioanal. Nucl. Chem., 314, 1083 (2017), https://doi.org/10.1007/s10967-017-5478-5

52 T. Liu, X. Han, Y. Wang, L. Yan, B. Du et al., J. Colloid Interface Sci., 508, 405 (2017), https://doi.org/10.1016/j.jcis.2017.08.067 
53 X. Zhu and G. Yan, J. Water Environ. Nanotechnol., $\quad \mathbf{1 4}, \quad 96 \quad$ (2016), https://doi.org/10.2965/jwet.15-072

54 A. Varma, S. V. Deshpande and J. F. Kennedy, Carbohyd. Polym., 55, $77 \quad$ (2004), https://doi.org/10.1016/j.carbpol.2003.08.005

55 N. Muhd Julkapli, H. Md Akil and Z. Ahmad, Compos. Interfaces, 18, $449 \quad$ (2011), https://doi.org/10.1163/156855411X610232

56 C. Cao, L. Xiao, C. Chen, X. Shi, Q. Cao et al., Powder Technol., 260, $90 \quad$ (2014), https://doi.org/10.1016/j.powtec.2014.03.025

57 S. Ahmed, A. Ali and J. Sheikh, Int. J. Biol. Macromol., $\quad$ 116, $849 \quad$ (2018), https://doi.org/10.1016/j.ijbiomac.2018.04.176

58 P. Sahariah and M. Másson, Biomacromolecules, 18, 3846

(2017) https://doi.org/10.1021/acs.biomac.7b01058

59 M. N. V. Ravi Kumar, React. Funct. Polym., 46, 1 (2000), https://doi.org/10.1016/S1381-5148(00)000389

60 P. O. Boamah, Y. Huang, M. Hua, J. Onumah, L. K. Sam-Amoah et al., Ecotoxicol. Environ. Saf., 129, 154

(2016),

https://doi.org/10.1016/j.ecoenv.2016.01.014

${ }^{61}$ P. O. Boamah, Y. Huang, M. Hua, Q. Zhang, J. Wu et al., Ecotoxicol. Environ. Saf., 116, 113 (2015), https://doi.org/10.1016/j.ecoenv.2015.01.012

${ }^{62}$ F. A. Bertoni, J. C. González, S. I. García, L. F. Sala and S. E. Bellú, Carbohyd. Polym., 180, 55 (2018), https://doi.org/10.1016/j.carbpol.2017.10.027

63 E. Guibal, Prog. Polym. Sci., 30, 71 (2005), https://doi.org/10.1016/j.progpolymsci.2004.12.001

${ }^{64}$ C. K. S. Pillai, W. Paul and C. P. Sharma, Prog. Polym. Sci., 34, $641 \quad$ (2009), https://doi.org/10.1016/j.progpolymsci.2009.04.001

65 C. Eiden, C. Jewell and J. Wightman, J. Appl. Polym. Sci., 25, $1587 \quad$ (1982), https://doi.org/10.1002/app.1980.070250807

${ }_{66}$ R. B Hernandez, A. Franco, O. Yola, A. LópezDelgado, J. Felcman et al., J. Mol. Struct., 877, 89 (2008), https://doi.org/10.1016/j.molstruc.2007.07.024 67 A. Debbaudt, M. Zalba, M. Ferreira and M. Gschaider, Macromol. Biosci., 1, 249 (2001), https://doi.org/10.1002/1616-

5195(20010801)1:63.0.CO;2-G

68 A. Domard, Int. J. Biol. Macromol., 9, 98 (1987), https://doi.org/10.1016/0141-8130(87)90033-X

69 G. Micera, S. Deiana, A. Dessi, P. Decock, B. Dubois et al., Inorg. Chim. Acta, 107, 45 (1985), https://doi.org/10.1016/S0020-1693(00)80688-X

70 M. Rhazi, J. Desbrières, A. Tolaimate, M. Rinaudo, P. Vottero et al., Polymer, 43, 1267 (2002), https://doi.org/10.1016/S0032-3861(01)00685-1

71 S. Schlick, Macromolecules, 19, 192 (1986), https://doi.org/10.1021/ma00155a030

72 N. C. Braier and R. A. Jishi, J. Mol. Struct., 499, 51 (2000), https://doi.org/10.1016/S0166-1280(99)002882
73 R. Lü, Z. Cao and G. Shen, J. Mol. Struct., 860, 80 (2008),

https://doi.org/10.1016/j.theochem.2008.03.013

74 R. Terreux, M. Domard, C. Viton and A. Domard, Biomacromolecules, $\quad 7, \quad 31 \quad$ (2006), https://doi.org/10.1021/bm0504126

75 J. R. Pan, C. Huang, S. Chen and Y.-C. Chung, Colloids Surf., A, 147, $359 \quad$ (1999), https://doi.org/10.1016/S0927-7757(98)00588-3

${ }^{76}$ Y. Peng, D. Chen, J. Ji, Y. Kong, H. Wan et al., Appl. Clay Sci., 74, 81 (2013), https://doi.org/10.1016/j.clay.2012.10.002

77 G. Kyzas and D. Bikiaris, Mar. Drugs, 13, 312 (2015), https://doi.org/10.3390/md13010312

78 W. S. W. Ngah and S. Fatinathan, J. Environ. Manag., $\quad 91, \quad 958 \quad$ (2010), https://doi.org/10.1016/j.jenvman.2009.12.003

${ }_{79}$ M. Rajiv Gandhi, N. Viswanathan and S. Meenakshi, Int. J. Biol. Macromol., 47, 146 (2010), https://doi.org/10.1016/j.ijbiomac.2010.05.008

80 M.-S. Chiou and H.-Y. Li, J. Hazard. Mater., 93, 233 (2002), https://doi.org/10.1016/S03043894(02)00030-4

${ }^{81}$ K. Z. Elwakeel, M. A. Abd El-Ghaffar, S. M. ElKousy and H. G. El-Shorbagy, Chem. Eng. J., 203, 458 (2012), https://doi.org/10.1016/j.cej.2012.07.001

82 Y. Kawashima, T. Handa, A. Kasai, H. Takenaka, S. Y. Lin et al., J. Pharm. Sci., 74, 264 (1985), http://dx.doi.org/10.1002/jps.2600740308

83 V. N. Tirtom, A. Dinçer, S. Becerik, T. Aydemir and A. Çelik, Chem. Eng. J., 197, 379 (2012), https://doi.org/10.1016/j.cej.2012.05.059

${ }_{84}$ Y. Wang, Y. Qi, Y. Li, J. Wu, X. Ma et al., J. Hazard. Mater., 260, 9 (2013), https://doi.org/10.1016/j.jhazmat.2013.05.001

${ }^{85}$ Y. Wu, Y. Wang, G. Luo and Y. Dai, Bioresour. Technol., $\quad \mathbf{1 0 0}, \quad 3459 \quad$ (2009), https://doi.org/10.1016/j.biortech.2009.02.018

${ }^{86}$ H.-Y. Zhu, R. Jiang, L. Xiao and W. Li, J. Hazard. Mater., $\quad$ 179, $\quad 251 \quad$ (2010), https://doi.org/10.1016/j.jhazmat.2010.02.087

87 J. E. Polifka and J. Habermann, in "Drugs During Pregnancy and Lactation (Third Edition)", edited by C. Schaefer, P. Peters and R. K. Miller, San Diego, 2015, pp. 225-249, https://10.1016/B978-0-12-4080782.00010-X

${ }^{88}$ B. Samiey, C.-H. Cheng and J. Wu, Materials (Basel), 7, 673 (2014), http://dx.doi.org/10.3390/ma7020673

89 A. Sabareeswaran, E. B. Ansar, P. R. V. Harikrishna Varma, P. V. Mohanan and T. V. Kumary, Nanomedicine, $\quad \mathbf{1 2}, 1523 \quad$ (2016), https://doi.org/10.1016/j.nano.2016.02.018

90 M. S. Seyed Dorraji, A. R. Amani-Ghadim, Y. Hanifehpour, S. Woo Joo, A. Figoli et al., Chem. Eng. Res. Des., 117, $309 \quad$ (2017), https://doi.org/10.1016/j.cherd.2016.10.043

${ }_{91}$ M. A. Barakat, Arabian J. Chem., 4, 361 (2011), https://doi.org/10.1016/j.arabjc.2010.07.019 
92 I. V. Pylypchuk, D. Kołodyńska, M. Kozioł and P. P. Gorbyk, Nanoscale Res. Lett., 11, 168 (2016), https://doi.org/10.1186/s11671-016-1363-3

93 Q. Peng, Y. Liu, G. Zeng, W. Xu, C. Yang et al., J. Hazard. Mater., 177, $676 \quad$ (2010), https://doi.org/10.1016/j.jhazmat.2009.12.084

94 D. H. K. Reddy and S.-M. Lee, Adv. Colloid Interface Sci., 201-202, $68 \quad$ (2013), https://doi.org/10.1016/j.cis.2013.10.002

95 G. Dodi, D. Hritcu, G. Lisa and M. I. Popa, Chem. Eng. J., 203, $130 \quad$ (2012), https://doi.org/10.1016/j.cej.2012.06.133

96 J. Castelló, M. Gallardo, M. A. Busquets and J. Estelrich, Colloids Surf., A, 468, 151 (2015), https://doi.org/10.1016/j.colsurfa.2014.12.031

97 A. Afkhami and R. Norooz-Asl, Colloids Surf., A, 346, 52

(2009),

https://doi.org/10.1016/j.colsurfa.2009.05.024

98 F.-L. Fan, Z. Qin, J. Bai, W.-D. Rong, F.-Y. Fan et al., J. Environ. Radioact., 106, 40 (2012), https://doi.org/10.1016/j.jenvrad.2011.11.003

99 M. Iram, C. Guo, Y. Guan, A. Ishfaq and H. Liu, J. Hazard. Mater., 181, $1039 \quad$ (2010), https://doi.org/10.1016/j.jhazmat.2010.05.119

${ }^{100}$ Y.-K. Sun, M. Ma, Y. Zhang and N. Gu, Colloids Surf., $\quad$ A, $\quad \mathbf{2 4 5}, \quad 15 \quad$ (2004), https://doi.org/10.1016/j.colsurfa.2004.05.009

${ }^{101}$ B. Zargar, H. Parham and A. Hatamie, Talanta, 77, 1328

(2009),

https://doi.org/10.1016/j.talanta.2008.09.011

${ }^{102}$ Y. Zhu, J. Hu and J. Wang, J. Hazard. Mater., 221222, 155

(2012),

https://doi.org/10.1016/j.jhazmat.2012.04.026

${ }^{103}$ H. Yan, L. Yang, Z. Yang, H. Yang, A. Li et al., J. Hazard. Mater., 229-230, $371 \quad$ (2012), https://doi.org/10.1016/j.jhazmat.2012.06.014

${ }^{104}$ M. Hua, S. Zhang, B. Pan, W. Zhang, L. Lv et al., J. Hazard. Mater., 211-212, 317 (2012), https://doi.org/10.1016/j.jhazmat.2011.10.016

${ }^{105}$ G.-Y. Li, Y.-R. Jiang, K.-L. Huang, P. Ding and J. Chen, J. Alloys Compd., 466, 451 (2008), https://doi.org/10.1016/j.jallcom.2007.11.100

${ }^{106}$ C. Yuwei and W. Jianlong, Chem. Eng. J., 168, 286 (2011), https://doi.org/10.1016/j.cej.2011.01.006

${ }^{107}$ H. Maleki, A. Simchi, M. Imani and B. F. O. Costa, J. Magn. Magn. Mater., 324, 3997 (2012), https://doi.org/10.1016/j.jmmm.2012.06.045

108 O. M. Lemine, K. Omri, B. Zhang, L. El Mir, M. Sajieddine et al., Superlattices Microstruct., 52, 793 (2012), https://doi.org/10.1016/j.spmi.2012.07.009

${ }^{109}$ B. Tural, N. Özkan and M. Volkan, J. Phys. Chem. Solids, $\quad 70, \quad 860 \quad$ (2009), https://doi.org/10.1016/j.jpcs.2009.04.007

${ }^{110}$ C. Hongtao, F. Yongmei, R. Wanzhong, Z. Tao, L. Hongying et al., Recent Pat. Nanotechnol., 3, 32 (2009),

http://dx.doi.org/10.2174/187221009787003302
111 W. Wu, Q. He and C. Jiang, Nanoscale Res. Lett., 3, 397 (2008), https://doi.org/10.1007/s11671-0089174-9

${ }^{112}$ L. Qiao and M. T. Swihart, Adv. Colloid Interface Sci., $\quad \mathbf{2 4 4}, \quad 199 \quad$ (2017), https://doi.org/10.1016/j.cis.2016.01.005

${ }^{113}$ P. Guardia, A. Labarta and X. Batlle, J. Phys. Chem. $\quad C, \quad \mathbf{1 1 5}, \quad 390 \quad$ (2011), https://doi.org/10.1021/jp1084982

${ }^{114}$ B. Shi, Y. Wang, J. Ren, X. Liu, Y. Zhang et al., J. Mol. Catal. B: Enzym., 63, 50 (2010), https://doi.org/10.1016/j.molcatb.2009.12.003

${ }^{115}$ P. E. Podzus, M. E. Daraio and S. E. Jacobo, Phys. $\begin{array}{llll}B, & 404, & 2710 & \text { (2009), }\end{array}$ https://doi.org/10.1016/j.physb.2009.06.093

${ }^{116}$ C. Wilhelm, C. Billotey, J. Roger, J. N. Pons, J. C. Bacri et al., Biomaterials, 24, 1001 (2003), https://doi.org/10.1016/S0142-9612(02)00440-4

117 A. P. Astalan, F. Ahrentorp, C. Johansson, K. Larsson and A. Krozer, Biosens. Bioelectron., 19, 945 (2004), https://doi.org/10.1016/j.bios.2003.09.005

118 A. Kaushik, R. Khan, P. R. Solanki, P. Pandey, J. Alam et al., Biosens. Bioelectron., 24, 676 (2008), https://doi.org/10.1016/j.bios.2008.06.032

${ }^{119}$ R. Jiang, Y.-Q. Fu, H.-Y. Zhu, J. Yao and L. Xiao, J. Appl. Polym. Sci., 125, E540 (2012), https://doi.org/10.1002/app.37003

${ }^{120}$ J. K. Oh and J. M. Park, Prog. Polym. Sci., 36, 168 (2011),

https://doi.org/10.1016/j.progpolymsci.2010.08.005

${ }^{121}$ W. Ma, F.-Q. Ya, M. Han and R. Wang, J. Hazard. Mater., 143, $296 \quad$ (2007), https://doi.org/10.1016/j.jhazmat.2006.09.032

${ }^{122}$ L.-Y. Zhang, X.-J. Zhu, H.-W. Sun, G.-R. Chi, J.X. Xu et al., Curr. Appl. Phys., 10, 828 (2010), https://doi.org/10.1016/j.cap.2009.10.002

${ }^{123}$ J. Zhi, Y. Wang, Y. Lu, J. Ma and G. Luo, React. Funct. Polym., 66, $1552 \quad$ (2006), https://doi.org/10.1016/j.reactfunctpolym.2006.05.006

${ }^{124}$ H. V. Tran, L. D. Tran and T. N. Nguyen, Mater. Sci. Eng. : $\quad C, \quad 30,304 \quad$ (2010), https://doi.org/10.1016/j.msec.2009.11.008

${ }^{125}$ Y. Chen and J. Wang, Nucl. Eng. Des., 242, 452 (2012),

https://doi.org/10.1016/j.nucengdes.2011.11.004

${ }^{126}$ E. Guibal, Sep. Purif. Technol., 38, 43 (2004), https://doi.org/10.1016/j.seppur.2003.10.004

${ }^{127}$ D. Kołodyńska, Chem. Eng. J., 173, 520 (2011), https://doi.org/10.1016/j.cej.2011.08.025

${ }^{128}$ M. Ahmaruzzaman and V. K. Gupta, Ind. Eng. Chem. Res., 50, $13589 \quad$ (2011), https://doi.org/10.1021/ie201477c

${ }^{129}$ T. M. Budnyak, I. V. Pylypchuk, V. A. Tertykh, E. S. Yanovska and D. Kolodynska, Nanoscale Res. Lett., 10, 87 (2015), https://doi.org/10.1186/s11671-0140722-1

${ }^{130}$ P. Kanmani, J. Aravind, M. Kamaraj, P. Sureshbabu and S. Karthikeyan, Bioresour. Technol., 
242,

295

(2017)

https://doi.org/10.1016/j.biortech.2017.03.119

${ }^{131}$ J. Xie, C. Li, L. Chi and D. Wu, Fuel, 103, 480 (2013), https://doi.org/10.1016/j.fuel.2012.05.036

${ }^{132}$ H. Fang, J. Huang, L. Ding, M. Li and Z. Chen, J. Wuhan Univ. Technol., Mater. Sci. Ed., 24, 42 (2009), https://doi.org/10.1007/s11595-009-1042-7

${ }^{133}$ Y. Haldorai, D. Kharismadewi and J.-J. Shim, Korean J. Chem. Eng., 32, 1688 (2015), https://doi.org/10.1007/s11814-014-0368-9

${ }^{134}$ P. H. Towler, J. D. Smith and D. R. Dixon, Anal. Chim. Acta, 328, 53 (1996), https://doi.org/10.1016/0003-2670(96)00080-3

${ }^{135}$ Y. Xiao, H. Liang and Z. Wang, Mater. Res. Bull., 48, 3910 (2013), https://doi.org/10.1016/j.materresbull.2013.05.099

${ }^{136}$ A. Javid, S. Ahmadian, A. A. Saboury, S. M. Kalantar and S. Rezaei-Zarchi, Chem. Biol. Drug Des., 82, 296 (2013), https://doi.org/10.1111/cbdd.12145

${ }^{137}$ H. Guolin, Z. Hongyan, X. S. Jeffrey and A. G. L. Tim, Ind. Eng. Chem. Res., 48, 2646 (2009), https://doi.org/10.1021/ie800814h

${ }^{138}$ H. Y. Zhu, Y. Q. Fu, R. Jiang, J. Yao, L. Xiao et al., Bioresour. Technol., 105, 24 (2012), https://doi.org/10.1016/j.biortech.2011.11.057

139 Y.-C. Chang, S.-W. Chang and D.-H. Chen, React. Funct. Polym., 66, $335 \quad$ (2006), https://doi.org/10.1016/j.reactfunctpolym.2005.08.006

${ }^{140}$ L. Fan, C. Luo, Z. Lv, F. Lu and H. Qiu, Colloids $\begin{array}{lllll}\text { Surf., } & B, & \mathbf{8 8}, & 574 & \text { (2011), }\end{array}$ https://doi.org/10.1016/j.colsurfb.2011.07.038

${ }^{141}$ G. Huang, C. Yang, K. Zhang and J. Shi, Chin. J. Chem. Eng., 17, 960 (2009), https://doi.org/10.1016/S1004-9541(08)60303-1

${ }^{142}$ N. Rahbar, Z. Ramezani and Z. Mashhadizadeh, Jundishapur J. Heal. Sci., 7, 30174 (2015), http://dx.doi.org/10.17795/jjhs-30174

${ }^{143}$ M. Monier, D. M. Ayad, Y. Wei and A. A. Sarhan, J. Hazard. Mater., 177, 962 (2010), https://doi.org/10.1016/j.jhazmat.2010.01.012

${ }^{144}$ M. Namdeo and S. K. Bajpai, Colloids Surf., A, 320, 161

(2008),

https://doi.org/10.1016/j.colsurfa.2008.01.053

${ }^{145}$ H. Yan, H. Li, H. Yang, A. Li and R. Cheng, Chem. Eng. J., 223, 402 (2013), https://doi.org/10.1016/j.cej.2013.02.113

${ }^{146}$ Y. Meng, D. Chen, Y. Sun, D. Jiao, D. Zeng et al., Appl. Surf. Sci., 324, $745 \quad$ (2015), https://doi.org/10.1016/j.apsusc.2014.11.028

${ }^{147}$ N. N. Thinh, P. T. B. Hanh, L. T. T. Ha, L. N. Anh, T. V. Hoang et al., Mater. Sci. Eng.: C, 33, 1214 (2013), https://doi.org/10.1016/j.msec.2012.12.013

148 A. A. Galhoum, M. G. Mafhouz, S. T. AbdelRehem, N. A. Gomaa, A. A. Atia et al., Nanomaterials (Basel), $\quad 5, \quad 154 \quad$ (2015), https://doi.org/10.3390/nano5010154

${ }^{149}$ L. Zhou, J. Xu, X. Liang and Z. Liu, J. Hazard. Mater., $\quad \mathbf{1 8 2}, \quad 518 \quad$ (2010), https://doi.org/10.1016/j.jhazmat.2010.06.062
${ }^{150}$ H. Jiang, P. Chen, S. Luo, X. Luo, X. Tu et al., J. Inorg. Organomet. Polym. Mater., 23, 493 (2012), https://doi.org/10.1007/s10904-012-9792-7

${ }^{151}$ H. Zhu, Y. Fu, R. Jiang, J. Yao, L. Liu et al., Appl.

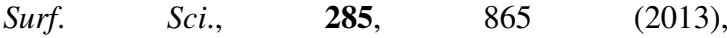
https://doi.org/10.1016/j.apsusc.2013.09.003

${ }^{152}$ J. Hu, G. Chen and I. M. C. Lo, Water Res., 39, 4528 (2005),

https://doi.org/10.1016/j.watres.2005.05.051

${ }^{153}$ K. G. Sreejalekshmi, K. A. Krishnan and T. S. Anirudhan, J. Hazard. Mater., 161, 1506 (2009), https://doi.org/10.1016/j.jhazmat.2008.05.002

${ }^{154}$ M. F. Hamza, M. M. Aly, A. A. Abdel-Rahman, S. Ramadan, H. Raslan et al., Materials (Basel), 10, 539 (2017), https://doi.org/10.3390/ma10050539

${ }^{155}$ B. Zhang, R. Hu, D. Sun, T. Wu and Y. Li, Sci. Rep., 8, 15397 (2018), https://doi.org/10.1038/s41598018-33925-7

${ }^{156}$ S. Banerjee and M. C. Chattopadhyaya, Arabian J. Chem., 10, 1629 (2017), https://doi.org/10.1016/j.arabjc.2013.06.005

${ }^{157}$ F. Fu and Q. Wang, J. Environ. Manag., 92, 407 (2011), https://doi.org/10.1016/j.jenvman.2010.11.011

${ }^{158}$ R. E. Morsi, A. M. Al-Sabagh, Y. M. Moustafa, S. G. ElKholy and M. S. Sayed, Egypt. J. Pet., 27, 1077 (2018), https://doi.org/10.1016/j.ejpe.2018.03.004

${ }^{159}$ K. Zargoosh, H. Abedini, A. Abdolmaleki and M. R. Molavian, Ind. Eng. Chem. Res., 52, 14944 (2013), https://doi.org/10.1021/ie401971w

${ }^{160}$ Y. Haldorai, A. Rengaraj, T. Ryu, J. Shin, Y. S. Huh et al., Mater. Sci. Eng. : B, 195, 20 (2015), https://doi.org/10.1016/j.mseb.2015.01.006

${ }^{161}$ V. Javanbakht, S. M. Ghoreishi, N. Habibi and M. Javanbakht, Powder Technol., 302, 372 (2016), https://doi.org/10.1016/j.powtec.2016.08.069

${ }^{162}$ T.-T. Li, Y.-G. Liu, Q.-Q. Peng, X.-J. Hu, T. Liao et al., Chem. Eng. J., 214, 189 (2013), https://doi.org/10.1016/j.cej.2012.10.055

${ }^{163}$ M. Özacar and İ. A. Şengil, Bioresour. Technol., 96, 791

(2005),

https://doi.org/10.1016/j.biortech.2004.07.011

${ }^{164}$ N. Rahbar, A. Jahangiri, S. Boumi and M. J. Khodayar, Jundishapur J. Nat. Pharm. Prod., 9, e15913 (2014), https://doi.org/10.17795/jjnpp-15913

${ }^{165}$ V. Nguyen and Q.-H. Pho, The Scientific World Journal, 2014, $273082 \quad$ (2014), https://doi.org/10.1155/2014/273082

${ }^{166}$ M. R. Lasheen, I. Y. El-Sherif, M. E. Tawfik, S. T. El-Wakeel and M. F. El-Shahat, Mater. Res. Bull., 80, 344 https://doi.org/10.1016/j.materresbull.2016.04.011

167 D. Yang, L. Qiu and Y. Yang, J. Chem. Eng. Data, 61, 3933

(2016),

https://doi.org/10.1021/acs.jced.6b00706

168 A. Sarı, M. Tuzen, Ö. D. Uluözlü and M. Soylak, Biochem. Eng. J., 37, 151 (2007), https://doi.org/10.1016/j.bej.2007.04.007 
${ }^{169}$ N. Le Thi Thanh, V. Le, M. Dao, Q. V. Nguyen, T. T. $\mathrm{Vu}$ et al., Chem. Eng. Commun., 1 (2019), https://doi.org/10.1080/00986445.2018.1558215

${ }^{170}$ K. Ezeh, I. Ogbu, K. Akpomie, N. Ojukwu and J. Ibe, Pacific J. Sci. Technol., 18, 251 (2017), http://www.akamaiuniversity.us/PJST18_1_251.pdf

${ }^{171}$ K. G. Akpomie, F. A. Dawodu and K. O. Adebowale, Alexandria Eng. J., 54, 757 (2015), https://doi.org/10.1016/j.aej.2015.03.025

${ }^{172}$ N. Barka, M. Abdennouri, M. El Makhfouk and S. Qourzal, J. Environ. Chem. Eng., 1, 144 (2013), https://doi.org/10.1016/j.jece.2013.04.008

${ }^{173}$ L. Zhang, Y. Zeng and Z. Cheng, J. Mol. Liq., 214, 175

(2016),

https://doi.org/10.1016/j.molliq.2015.12.013

${ }^{174}$ L. Fan, C. Luo, Z. Lv, F. Lu and H. Qiu, J. Hazard. Mater., $\quad$ 194, $193 \quad$ (2011), https://doi.org/10.1016/j.jhazmat.2011.07.080

175 A. M. Donia, A. A. Atia and K. Z. Elwakeel, Hydrometallurgy, $\quad \mathbf{8 7}, 197 \quad$ (2007), https://doi.org/10.1016/j.hydromet.2007.03.007

${ }^{176}$ S. Zhang, Y. Zhou, W. Nie, L. Song and T. Zhang, Ind. Eng. Chem. Res., 51, 14099 (2012), https://doi.org/10.1021/ie301942j

177 A. M. Aljeboree, A. N. Alshirifi and A. F. Alkaim, Arabian J. Chem., 10, S3381 (2017), https://doi.org/10.1016/j.arabjc.2014.01.020

${ }^{178}$ K. Shahul Hameed, P. Muthirulan and M. Meenakshi Sundaram, Arabian J. Chem., 10, S2225 (2017), https://doi.org/10.1016/j.arabjc.2013.07.058

${ }^{179}$ M. A. Ahmadi, S. Zendehboudi, A. Shafiei and L. James, Ind. Eng. Chem. Res., 51, 9894 (2012), https://doi.org/10.1021/ie300269c

${ }^{180}$ P. Pal, D. Mohan, Y. Dhoble and S. Bhattacharjee, J. Metall. Mater. Sci., 58, 1 (2016)

${ }^{181}$ A. O. Dada, A. Olalekan, A. Olatunya and O. Dada, J. Appl. Chem., 3, 38 (2012), https://doi.org/10.9790/5736-0313845

182 Y. S. Ho and G. McKay, Process Biochem., 34, 451 (1999), https://doi.org/10.1016/S0032-9592(98)001125

${ }^{183}$ L. Zhou, C. Gao and W. Xu, ACS Appl. Mater. Interfaces, $\quad \mathbf{2}, 1483 \quad$ (2010), https://doi.org/10.1021/am100114f

${ }^{184}$ A. Esmaeli, M. Jokar, M. Kosha, E. Daneshvar, H. Zilouei et al., Chem. Eng. J., 217, 329 (2013), https://doi.org/10.1016/j.cej.2012.11.038

${ }^{185}$ J. Wu and H.-Q. Yu, Bioresour. Technol., 98, 253 (2007), https://doi.org/10.1016/j.biortech.2006.01.018

${ }^{186}$ G. Feng, J. Ma, X. Zhang, Q. Zhang, Y. Xiao et al., J. Colloid Interface Sci., 538, 132 (2019), https://doi.org/10.1016/j.jcis.2018.11.087

187 V. T. Le, M. U. Dao, H. S. Le, D. L. Tran, V. D. Doan et al., Environ. Technol., 40, 1 (2019), https://doi.org/10.1080/09593330.2019.1584250
${ }^{188}$ L. V. Thuan, T. B. Chau, T. T. K. Ngan, T. X. Vu, D. D. Nguyen et al., Environ. Technol., 39, 1745 (2018),

https://doi.org/10.1080/09593330.2017.1337236

${ }^{189}$ H. Zhang, L. Peng, A. Chen, C. Shang, M. Lei et al., Carbohyd. Polym., 214, 276 (2019), https://doi.org/10.1016/j.carbpol.2019.03.056

${ }^{190}$ J. D. O. Marques Neto, C. R. Bellato and D. D. C. Silva, Chemosphere, 218, $391 \quad$ (2019), https://doi.org/10.1016/j.chemosphere.2018.11.080

${ }^{191}$ K. Pandi, N. Viswanathan and S. Meenakshi, Int. J. Biol. Macromol., 132, $600 \quad$ (2019), https://doi.org/10.1016/j.ijbiomac.2019.03.115

192 A. Azari, M. Noorisepehr, E. Dehghanifard, K. Karimyan, S. Y. Hashemi et al., Int. J. Biol. Macromol., $\quad$ 131, $633 \quad$ (2019), https://doi.org/10.1016/j.ijbiomac.2019.03.058

${ }^{193}$ C. Zheng, H. Zheng, Y. Wang, Y. Sun, Y. An et al., J. Hazard. Mater., 367, $492 \quad$ (2019), https://doi.org/10.1016/j.jhazmat.2018.12.120

${ }^{194}$ Y. Chen and J. Wang, Nucl. Eng. Des., 242, 445 (2012),

https://doi.org/10.1016/j.nucengdes.2011.10.059

195 S. Sheshmani, A. Ashori and S. Hasanzadeh, Int. J.

Biol. $\quad$ Macromol., $\quad$ 68, $218 \quad$ (2014), https://doi.org/10.1016/j.ijbiomac.2014.04.057

${ }^{196}$ W. You, H.-C. Liu, J.-W. Cao, Y.-L. Shen and W. Chen, Environ. Sci., 39, $5532 \quad$ (2018), https://doi.org/10.13227/j.hjkx.201803074

${ }^{197}$ K. Kavosi Rakati, M. Mirzaei, S. Maghsoodi and A. Shahbazi, Int. J. Biol. Macromol., 130, 1025 (2019), https://doi.org/10.1016/j.ijbiomac.2019.02.033

198 J. Wu, X. Cheng and G. Yang, Int. J. Biol. Macromol., $\quad \mathbf{1 2 5}, \quad 404 \quad$ (2018), https://doi.org/10.1016/j.ijbiomac.2018.11.212

${ }^{199}$ L. Li, H. Duan, X. Wang and C. Luo, Int. J. Biol. Macromol., $\quad \mathbf{7 8 ,} \quad 17 \quad$ (2015), https://doi.org/10.1016/j.ijbiomac.2015.01.014

${ }^{200}$ W. Sun, L. Li, C. Luo and L. Fan, Int. J. Biol. Macromol., $\quad 85, \quad 246 \quad$ (2016), https://doi.org/10.1016/j.ijbiomac.2015.09.061

${ }^{201}$ L. Fan, C. Luo, X. Li, F. Lu, H. Qiu et al., J. Hazard. Mater., 215-216, $272 \quad$ (2012), https://doi.org/10.1016/j.jhazmat.2012.02.068

${ }^{202}$ J. Heydaripour, M. Gazi, A. A. Oladipo and H. O. Gulcan, Int. J. Biol. Macromol., 123, 1125 (2019), https://doi.org/10.1016/j.ijbiomac.2018.11.168

${ }^{203}$ K. Wang, H. Ma, S. Pu, C. Yan, M. Wang et al., J. Hazard. Mater., 362, $160 \quad$ (2019), https://doi.org/10.1016/j.jhazmat.2018.08.067

${ }^{204}$ V. Sureshkumar, S. C. G. Kiruba Daniel, K. Ruckmani and M. Sivakumar, Appl. Nanosci., 6, 277 (2016), https://doi.org/10.1007/s13204-015-0429-3 